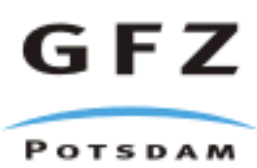

Originally published as:

Thomas, R., Davidson, P., Rhede, D., Leh, M. (2009): The miarolitic pegmatites from the Königshain: a contribution to understanding the genesis of pegmatites. - Contributions to Mineralogy and Petrology, 157, 4, 505-523

DOI: $10.1007 / \mathrm{s} 00410-008-0349-2$. 


\title{
The miarolitic pegmatites from the Königshain: a contribution to understanding the genesis of pegmatites
}

\author{
Rainer Thomas ${ }^{1)}$, Paul Davidson ${ }^{2)}$, Dieter Rhede ${ }^{1)}$ and Michael Leh ${ }^{3)}$ \\ 1) GeoForschungsZentrum Potsdam, Telegrafenberg, D-14473 Potsdam, Germany \\ 2) ARC Centre of Excellence in Ore Deposits, University of Tasmania, Hobart 7001, \\ Australia \\ 3) Oberlausitzische Gesellschaft der Wissenschaften e.V., \\ Neuer Weg 6, Neschwitz/Bautzen, Germany
}

\begin{abstract}
In this paper we show, that the crystallization of miarolitic pegmatites at Königshain started at about $700^{\circ} \mathrm{C}$, in melts containing up to 30 mass $\%$ water. Such high water concentration at low pressures (1-3 kbar) is only possible if the melts are peralkaline. Such peralkaline melts are highly corrosive, and reacted with the wall rock - here the granite host forming the graphic granite zone, in part via a magmatic-metasomatic reaction. With cooling, the water concentration in some melt fractions increased up to 50 mass $\% \mathrm{H}_{2} \mathrm{O}$. The meltdominated system ends below $600^{\circ} \mathrm{C}$ and passes into a fluid-dominated system, the beginning of which is characterized by strong pressure fluctuations, caused by the change of $\mathrm{OH}^{-}$and $\mathrm{CO}_{3}{ }^{2-}$ in the melt, to molecular water and $\mathrm{CO}_{2}$. We note two generations of smoky quartz, one crystallized above the $\beta$ - $\alpha$-transition of quartz $\left(\approx 573^{\circ} \mathrm{C}\right)$, and one below, both of which contain melt inclusions. This indicates that some melt fraction remains during at least the higher-temperature portion of the growth of minerals into the miarolitic cavity, contradicting the view that minerals growing into a pegmatite chamber only do so from aqueous fluids.

We show that the Königshain miarolitic pegmatites are part of the broad spectrum of pegmatite types, and the processes active at Königshain are representative of processes found in most granitic pegmatites, and are thus instructive in the understanding of pegmatite formation in general, and constraining the composition and characteristics of pegmatiteforming melts.
\end{abstract}

Keywords Granitic pegmatites $\cdot$ Miarolitic pegmatites $\cdot$ Melt and fluid inclusion 


\section{Introduction}

One fundamental problem in the study of pegmatites is the vast range and variety present among pegmatites, from a few centimeters, to hundreds of meters in size, and from simple granitic compositions, to highly exotic compositions extremely enriched in rare elements, sometimes present as crystals of rare and often magnificent minerals, occasionally to several meters in size. Not surprisingly the large rare-element enriched pegmatites tend to receive most attention, but it is noted even in regions which contain examples of these extreme rareelement enriched pegmatites that the great majority of pegmatites have simple forms and compositions (Brotzen 1959; London 1992); however, some features remain common to both. One common feature is the general association of granitic pegmatites with late-magmatic processes. Another common feature is evidence for late-stage flow of material through partially solidified magma to form the pegmatite. A number of examples from Australia (summarized in Candela and Blevin 1995) show small-scale (cm - meter) pegmatites occurring as 3-dimensionally linked networks, commonly in the apices of granitic intrusions. These linked miarolitic cavities, now filled with pegmatite, were used by Candela and Blevin (1995) to demonstrate strong melt permeability in magma bodies. Similar 3-D linked pathways were also observed in the case of Königshain, and similar results are presented by Janeczek (2007) in the nearby pegmatites from Strzegom (Striegau) in West Poland. In this paper, we will examine the crystallization of miarolitic pegmatites from the Königshain granite, E Germany (miarolitic class, Černý and Ercit 2005), with a view to extracting features from small-scale pegmatites of simple composition that may have relevance to the genesis to large-scale bodies.

Melt and fluid inclusions from the Königshain miarolitic pegmatites provide us with important constraints to the temperature, chemistry, concentration, and physical parameters of the mineral-forming media. Water-rich melt inclusions have been found in graphic quartz at the beginning of the pegmatite stage and in early smoky quartz, providing constraints on the composition and characteristics of pegmatite-forming melts. That the melt-dominated stage ends just below $575^{\circ} \mathrm{C}$ is indicated by the minimum trapping temperatures of extremely water-rich melt inclusions co-trapped with vapor-rich fluid inclusions in smoky quartz. Intermediate between the melt-dominated and the low-temperature hydrothermal conditions $\left(575\right.$ and $\left.400^{\circ} \mathrm{C}\right)$, there has only been a limited amount of information about the pegmatiticforming media, we provide evidence for a variable mix of extremely water-rich silicate melts, silica gels, and hydrothermal fluids. The end of the hydrothermal stage is characterized by a 
remarkably uniform low-temperature, low-salinity, rarely $\mathrm{CO}_{2}$-rich fluid inclusions in late smoky quartz, transparent albite crystals and in generally cubic fluorite.

In this contribution, we show that the Königshain miarolitic pegmatites have a gradual transition into the enclosing parental granite, and crystallized from residual melts in situ, without any evidence of emplacement from a discrete magma pulse within the parent intrusion (Beus 1966). At most there has been small-scale localized inflow of a volatile-rich late-magmatic fluid.

\section{Local and regional geology}

The Variscan granites at Königshain, "Königshainer Stockgranit”, were emplaced at the north-eastern margin of the Lusatian Granitoid Complex in SE Germany about $10 \mathrm{~km}$ NW of Görlitz (Fig. 1). This small complex $\left(36.3 \mathrm{~km}^{2}\right)$ belongs to the Saxothuringian zone of the mid-European Hercynides and is located at the northern margin of the Bohemian massif. According to Möbus and Lindert (1967), the granites are biotite-monzogranites. The granites are medium-grained or sporadically coarse-grained rocks, typically of light grey and white patterned color, and porphyritic, equigranular and fine-grained types can be distinguished. Selected average compositions are given by Ebert (1943), Möbus and Lindert (1967), and Hecht et al. (1999). Given the alumina saturation index of 0.96 to 1.05 (alumina saturation index, $\mathrm{ASI}=$ molar ratio $\left.\left[\mathrm{Al}_{2} \mathrm{O}_{3} /\left(\mathrm{CaO}+\mathrm{Li}_{2} \mathrm{O}+\mathrm{Na}_{2} \mathrm{O}+\mathrm{K}_{2} \mathrm{O}+\mathrm{Rb}_{2} \mathrm{O}+\mathrm{Cs}_{2} \mathrm{O}\right)\right]\right)$, the granites are weakly peraluminous to metaluminous.

The granites of Königshain in the NW of Görlitz are characterized by abundant isolated miarolitic cavities from $1 \mathrm{~cm}$ to more than $1 \mathrm{~m}$ in diameter. The larger cavities usually have an elongate, flat, lenticular form, and the smaller ones are spherical. Pegmatites of this type were found in the granite quarries from Arnsdorf, Dobschütz, Hilbersdorf, Königshain, Mengelsdorf, and Thiemendorf. Vein-like pegmatite bodies are very rare, and are usually less than $20 \mathrm{~cm}$ thick.

Studies of the pegmatites from Königshain go back almost 230 years (von Schachtmann 1780; cited in Förster et al. 2005 and Lange et al. 2004), and the Königshain pegmatites have often been referred to in the mineralogical literature.

\section{Sample descriptions}


The most samples in this study were obtained from the Hilbersdorf quarry by R.T. in 1957 and M.L. in 1961. Samples from Königshain, and Dobschütz were used for comparison. Generally, all samples from the different locations (see Fig. 1) contain similar inclusion population.

Most miarolitic cavities have an outer rim of graphic granite which shows a gradational contact with the granite. The graphic granite contains quartz, K-feldspar and biotitesiderophyllite, showing increasing grain size towards the cavity, large biotite crystals are rare, but if present, the crystals are often bent and enclosed in blocky quartz. The walls of the miarolitic cavities are made up of K-feldspar crystals with graphic intergrowths of quartz, and are lined with larger feldspar (up to $10 \mathrm{~cm}$ ) and smoky quartz crystals projecting into the open space of miarolitic cavities. The smoky quartz crystals appear to nucleate on rod-like quartz glyphs in the graphic granite. Some of the microcline is amazonite, in which case the freegrown quartz on the microcline is very dark, almost black (morion). Epitaxial growth of water-clear albite crystals on K-feldspar is characteristic. In some cavities, albite replaces the K-feldspar, or forms crust on the other minerals. Smoky quartz crystals are often coated with thin olive-green flakes of clinochlore. Minerals such as beryl, bazzite, euclase, monazite, phenakite, topaz, tourmaline, zircon, xenotime, molybdenite occur as small and relatively rare crystals.

Later mineralization in the open space of the miarolitic cavities includes colorless albite, late, sometimes colorless quartz, fluorite of various colors, and as a very late phase stilbiteCa. A concise list and description of the minerals found in the pegmatites of the Königshain massif is given in Lange et al. (2004). Currently over 80 different minerals have been described (see also Witzke and Giesler 2001).

In addition to quartz, feldspars and traces of Fe-rich polylithionite $\left(\mathrm{KLi}_{2} \mathrm{Al}\left[(\mathrm{F}, \mathrm{OH})_{2} \mid \mathrm{Si}_{4} \mathrm{O}_{10}\right]\right)$, the graphic granite is characterized by graphic intergrowths with zircon (Fig. 2a). The first generation of fluorite in the Königshain pegmatite occurs in the zircon glyphs as small grains in the graphic granite. Here, the fluorite forms irregular grains approximately 2 - $4 \mathrm{~mm}$ in diameter occurring on grain boundaries between quartz and feldspar, mostly attached to zircon glyphs (Fig. 2b). These fluorite aggregates contain many small crystals of monazite, xenotime, zircon, bastnäsite-(Ce) and fluocerite-(Ce) (Fig. 2b, c). The mineral-inclusion-free areas of the fluorite are generally colorless to light blue; however, adjacent to monazite crystals the fluorite is purple in color due to radiation-induced (metamict) damage to the crystal lattice. The first generation fluorite contains only sparse primary multiphase inclusions, which can be interpreted as melt inclusions, and also 
secondary fluid inclusions similar to those in the low-temperature fluorite. However, some of these inclusions contain small $\mathrm{Li}_{2} \mathrm{BeF}_{4}$ daughter crystals. Thermometric measurements could not be performed because of the tendency of the host to decrepitate. Euhedral crystals of tourmaline, late smoky quartz, water-clear albite, and variously colored second generation fluorites projecting into the miarolitic cavities contain only fluid inclusions.

We have also undertaken a detailed study of a large $(10 \mathrm{~cm})$ colorless to light blue lowtemperature fluorite crystal from a miarolitic cavity in the granite from the Hilbersdorf quarry in the Königshain massif. The principal forms of this crystal are the $\{111\}$ faces; the $\{100\}$ and $\{110\}$ faces are subordinate. The [111] surfaces are perfectly smooth, although the [11-1] surfaces are very rough due to abundant small growth pyramids. The measured interplanar angle is $70^{\circ} 40^{\prime}$. Primary fluid inclusions with several different solid phases (quartz, albite, orthoclase, muscovite, clinochlore and ungarettiite) are exclusively arranged in the [11-1] planes, as stacked planes of fluid inclusions about $100 \mu \mathrm{m}$ apart (Fig. 3a, b). Ungarettiite $\left[\mathrm{Na}_{3} \mathrm{Mn}_{2}^{2+}{ }_{2} \mathrm{Mn}^{3+}{ }_{3} \mathrm{Si}_{8} \mathrm{O}_{24}\right]$ an anhydrous amphibole was identified with Raman spectroscopy according to the RUFF data base (Downs 2006). Inclusions in the [111] planes are extremely rare, and are always two-phase inclusions without any solid phases (Fig. 3c), but with the same homogenization behavior as the multiphase inclusions in the [11-1] planes.

\section{Experimental and analytical methods}

The melt and fluid inclusions found in the Königshain miarolitic pegmatite are similar, if not identical to inclusions found in a number of other pegmatites which have been published by Thomas et al. 2000, 2003, 2006b (among others). In consequence, the same analytical techniques and conditions were used in order to maintain consistency. Melt inclusions were homogenized using conventional horizontal cold-seal pressure vessel technique (Thomas et al. 2000). Hydrothermal rapid-quench homogenization experiments were performed (Veksler and Thomas 2002). Microthermometric measurements were performed using a calibrated LINKAM THMS 600 heating and freezing stage, using the conditions described in (Thomas et al. 2003, 2005). The salinity of the inclusions was estimated using the empirical equations (Bakker 2003; program AqSo2e, version 03/02) for freezing-point-depression of aqueous solutions corresponding to the $\mathrm{CaCl}_{2}-\mathrm{NaCl}-\mathrm{H}_{2} \mathrm{O}$ system with one or two dissolved salts. For solutions with significant amounts of carbonates we used the system $\mathrm{Na}_{2} \mathrm{CO}_{3}-\mathrm{NaCl}-\mathrm{H}_{2} \mathrm{O}$ (Makarov 1933) for the cryometric measurements, and the cryometric criteria demonstrated by Borisenko (1977). Therefore, the determined carbonate concentrations are $\mathrm{Na}_{2} \mathrm{CO}_{3}$ 
equivalent concentrations. According to Nývlt (1977) the solubility of the main alkali carbonates $(\mathrm{Li}, \mathrm{Na}, \mathrm{K})$ at $20^{\circ} \mathrm{C}$ are $1.31,18.1,52.5$ mass $\%$, respectively.

Raman spectra of mineral phases and water concentrations of some of the volatile-rich, type-A and type-B melt inclusions from the graphic granite and smoky quartz from the miarolitic cavities were determined by confocal Raman spectroscopy following the method by Thomas (2000) and Thomas and Davidson (2006). Carbonates in the fluid phases (type-B melt inclusions and fluid inclusions) were determined with Raman spectroscopy according to Oliver and Davis (1973) using the relationship of the concentration and the band position between $1,376 \mathrm{~cm}^{-1}(8.0 \mathrm{~mol} / \mathrm{l})$ and $1,382 \mathrm{~cm}^{-1}(0.01 \mathrm{~mol} / \mathrm{l})$. Note that the carbonate frequencies are virtually independent of alkali metal cations ( $\mathrm{Li}, \mathrm{Na}, \mathrm{K}, \mathrm{Rb}, \mathrm{Cs}$ ).

Microprobe analyses were performed on a Cameca SX50 and a SX100 electron microprobe at GFZ, Potsdam, using analytical conditions described in (Thomas et al. 2003, 2005). Additional measurements of REE-minerals were carried out with a JEOL thermal field emission electron-probe JXA-8500 F (HYPERPROBE) at GFZ. Beam conditions were an accelerating voltage of $20 \mathrm{kV}$, a beam current of $10 \mathrm{nA}$, and different beam diameters depending on the size of the grains (focussed beam or 1-2 $\mu \mathrm{m}$ beam diameter). The counting times on the peak are $20 \mathrm{~s}$ for Fe and Zr, $30 \mathrm{~s}$ for F, Al, Si, P and Ca and $50 \mathrm{~s}$ for Y, REEs, Hf, $\mathrm{Pb}$, Th and U. The matrix corrections were performed following the Armstrong-CITZAF method (Armstrong 1991). X-ray lines and background offsets were selected to minimize interferences or were empirically corrected (e.g., Åmli and Griffin 1975; Roeder 1985).

\section{Results}

Melt inclusion in graphic granite quartz

In graphic granite quartz in this study, there are two types of melt inclusions: (1) $\mathrm{H}_{2} \mathrm{O}$-poor type-A and (2) $\mathrm{H}_{2} \mathrm{O}$-rich type-B melt inclusions which differ mainly in the water content. In Thomas et al. (2000), these were interpreted as resulting from cooling and concomitant fractional crystallization from about 700 to $500^{\circ} \mathrm{C}$, which induced development of two immiscible conjugate melts along the opening solvus (Thomas et al. 2006a, b). Near the critical point of the pseudobinary melt- $\mathrm{H}_{2} \mathrm{O}$ system, the melt compositions merge.

Table 1 gives the mean composition of the inclusion glass of large type-A melt inclusions in quartz of graphic granite (illustrated in Figs. 5-9 in Thomas et al. 2006a) from a miarolitic pegmatite in the Königshain granite (Fig. 4a). Immediately after quenching and opening the 
inclusion by polishing under oil, the glass was very water-rich $(18.4 \pm 0.8$ mass $\%$ by Raman spectroscopy). This value was not stable with time, after electron microprobe measurements, the water concentration reduced to $10.1 \pm 0.25$ mass $\%$ due to structural changes in the exposed glass.

In close proximity to this inclusion type, there are also type-B melt inclusions (Table 1, column 4) with apparently higher water content. A very conservative volume estimation gives a water content of about 32 mass $\%$. Such high water content makes it impossible to determine the bulk composition of this inclusion type by microprobe techniques, since such material is not stable in air, and opening such inclusions would destroy the glass.

In the fluid phase of some type-B melt inclusions, we detected nahcolite daughter crystals (identified with Raman spectroscopy). The melting temperature $\mathrm{t}_{\mathrm{S}-\mathrm{NaHCO} 3}=106^{\circ} \mathrm{C}$ gives a $\mathrm{NaHCO}_{3}$ concentration of approximately 19.8 mass\% (Borisenko 1974); however, the $\mathrm{NaHCO}_{3}-\mathrm{NaCl}-\mathrm{H}_{2} \mathrm{O}$ systematics at higher temperatures is not well constrained.

Melt and fluid inclusions in smoky quartz crystals

In general, the free-grown smoky quartz crystals from the miarolitic cavities in the Königshain granite are dominated by two-phase fluid inclusions (single-phase aqueous liquid + vapour bubble); however, in some crystals pure $\mathrm{CO}_{2}$ or $\mathrm{CO}_{2}$-rich fluid inclusions are also present. Fluid inclusions with daughter mineral phases such as halite or sylvite were not observed. However, fluid inclusions in smoky quartz often contain calcite daughter crystals. The abundance of fluid inclusions makes the identification of primary melt inclusions very difficult, but they are generally rare, and may be absent in parts of some crystals.

Type 1 smoky quartz In some large smoky quartz crystals (Fig. 5a), three different zones can be recognized from core to rim: (1) a central zone with melt inclusions, and predominantly secondary fluid inclusions, (2) a cellular quartz zone (generally $80-90 \%$ of the crystal volume) and (3) a small, sharp zone of colorless quartz, poor in fluid inclusions.

The cell size (Fig. 5b) in the cellular quartz zone increases upwards from the base of the crystal. The center of such cells is nearly inclusion-free and the cell walls are decorated with many small fluid inclusions (Fig. 5b), which give the smoky quartz a cloudy appearance in thick sections.

Cellular quartz (Voznyak et al. 1984) is a commonly observed texture in pegmatitic quartz, and is probably the result of systematic (possibly simultaneous) decrepitation of large numbers of fluid inclusions. This results in the linking up of decrepitation cracks into semi- 
regular cells or more irregular intersecting veils. Several mechanisms for the more or less simultaneous decrepitation of huge numbers of fluid inclusions have been suggested. One is that the $\beta-\alpha$-transition and consequent volume change during cooling (see Voznyak et al. 1984). Another, possibly related cause is the extra stress build up due to change of speciation of $\mathrm{OH}^{-}$and $\mathrm{CO}_{3}{ }^{2-}$ to molecular water and $\mathrm{CO}_{2}$ in the melt inclusions, and possibly in the complete system (see Burnham 1979).

Near the base of the growth zone in the large crystal, we found abundant small melt inclusions with diameters up to $60 \mu \mathrm{m}$ (see Figs 4a-d, 6a-d). According to the terminology of Thomas et al. (2000), there are both types of melt inclusions in a single growth zone: waterpoor type-A and water-rich type-B melt inclusions, together with high-temperature, vaporrich fluid inclusions, randomly distributed, as well as small alkali carbonate-rich inclusions with nahcolite $\left[\mathrm{NaHCO}_{3}\right]$ and zabuyelite $\left[\mathrm{Li}_{2} \mathrm{CO}_{3}\right]$.

The presence of $\mathrm{CO}_{2}$ in the vapor bubble of the type- $\mathrm{B}$ melt inclusions after rehomogenization, and the relatively high $\mathrm{CO}_{3}{ }^{2-}$ concentration in the fluid phase determined with Raman spectroscopy, indicates that pegmatite-forming melt contains relatively high concentration of $\mathrm{CO}_{3}{ }^{2-}$ ions. In some cases during rapid cooling of homogenized inclusions, we observed the formation of a separate $\mathrm{CO}_{2}$ and $\mathrm{H}_{2} \mathrm{O}$-rich bubbles in the glass (Fig. 4b), indicating that the change in speciation $\left(\mathrm{CO}_{3}{ }^{2-}\right.$ to $\left.\mathrm{CO}_{2}\right)$ happens at lower temperature than the exsolution of the water-rich sub-phase.

Type 2 smoky quartz This type is characterized by a lack of cellular textures, and well formed growth zones parallel to the rhombohedra marked by fluid and melt inclusions. By implication this quartz crystallized at temperatures lower than the $\beta-\alpha$ transition temperature, $573^{\circ} \mathrm{C}$

Before re-homogenization the melt inclusion contain muscovite, dawsonite $\left[\mathrm{NaAl}\left(\mathrm{CO}_{3}\right)(\mathrm{OH})_{2}\right]$, and commonly a small calcite crystal, as well as carbonate-rich aqueous fluid and a vapor bubble (see also Sirbescu and Nabelek 2003a, b). The volume of the carbonate-rich fluid is highly variable, depending of the inclusion type. Type-A melt inclusions contain only a small amount of fluid, as well as equal amounts of dawsonite and muscovite. In contrast, we have estimated following phase composition (in volume proportions) for a few type-B melt inclusions: dawsonite 0.30 , muscovite 0.20 , calcite 0.02 , and carbonate-rich liquid 0.48 . These data produce an estimate the composition of the type-A and type-B melts (Table 2), which shows relatively high concentration of carbonates in both melt types. The type-B melt is characterized by a higher alkali concentration and a very high 
concentration of water. Table 1, column 5, gives the composition of the type-A melt (Fig. 7a, b), which in this case is similar to type-B melt, partly due to proximity to the critical point on the miscibility solvus, and to reaction with the wall-rocks during crystallization of the graphic zone (Table 1, columns 6,7 ). In column 8 is given the composition of a gel-like substance in small inclusions coexisting with a water-rich melt and a fluid.

The existence of melt inclusions in type 2 smoky quartz provides a critical challenge to current theories of the miarolitic pegmatite genesis. According to Černý and Ercit (2005) and London (2008) all free-grown minerals in the miaroles should be crystallized out of aqueous solutions and not from melts. The presence of the same silicate melts as inclusions in quartz which crystallized both above and below the $\beta-\alpha$ quartz transition $\left(\approx 573^{\circ} \mathrm{C}\right)$ implies that the cut-off between melts and fluids is not as clear-cut as previously assumed.

\section{Water content of the melt inclusions in smoky quartz crystals}

We measured $\mathrm{H}_{2} \mathrm{O}$ concentrations in melt inclusions in growth zones in the cores of smoky quartz crystals from miarolitic cavities at Königshain (type 1 smoky quartz). The inclusion glasses of 23 relatively large melt inclusions (40 - 50 $\mu \mathrm{m}$ in diameter) re-homogenized at $650^{\circ} \mathrm{C}$ and $2 \mathrm{kbar}$ contain (by Raman measurement) $8.2 \pm 0.6$ mass \% water, independent of the inclusion type. The inclusion glass of small melt inclusions in type 2 smoky quartz contains $11.4 \pm 0.5$ mass $\%$ water (see Table 1 ).

However, type-B melt inclusions are composed of the homogeneous glass ( 8.2 mass $\%$ water), plus a water-rich "bubble". In some type-B melt inclusions of the same sample, we have observed a second glass (Fig. 6b) with about 19 mass $\% \mathrm{H}_{2} \mathrm{O}$, inside of the main glass phase (with 8.2 mass $\% \mathrm{H}_{2} \mathrm{O}$ ), probably formed by liquid-liquid immiscibility during the quenching process. This observation suggests that the mean of 8.2 mass $\%$ water in the glass is an "equilibrium concentration" determined by the experimental conditions (here $650^{\circ} \mathrm{C}$ and 2 kbar).

The glass portion of the type-B melt inclusion varies from about 70 to $20 \mathrm{vol} \%$. The bulk water concentration of such inclusions can be estimated from the volume proportions of each phase in the inclusions, and gives a bulk concentration range from about 15 to 50 mass\% water. According to Audétat and Keppler (2004) such high water content corresponds to viscosities of about 1,000 to 3 Pa.s - the viscosity of light paraffin oil and the viscosity of glycerine at room temperature, respectively. For comparison, the viscosity of molten glass at its working temperature is about $10^{5}$ Pa.s. 
Careful examination of the water-rich melt inclusions shows that some are surrounded by healed fissures decorated by many small fluid inclusions. This suggests that the melt inclusions have decrepitated, possibly due to the $\beta-\alpha$-transition in nature, and the pressure increase as a result of the changing in speciation, and thus lost significant amounts of water. Therefore, although quite large, the estimated water concentrations are only minimum values for both melt inclusion types. For the type-B melt inclusions in the smoky quartz from Königshain we have estimated a mean of 30 mass $\%$.

\section{Melt inclusions after re-homogenization: supplementary observations}

Using the hydrothermal rapid-quench technique (see techniques, Electronic supplementary material) some type-B melt inclusions can be quenched to a homogeneous glass which has a Raman spectrum which is different to both water or an water-rich aluminosilicate glass. This glass-like type-B melt phase is unstable, and after a few hours, or during intensive laser excitation, the metastable glass disassociates at room temperature into a stable aluminosilicate glass, a water-rich liquid and a vapor phase, forming the characteristic type-B melt inclusion (see Fig. 8a, b).

In the separate fluid phase of some type-B melt inclusions we detected nahcolite daughter crystals with Raman spectroscopy, mostly having crystallized some weeks after quenching, indicating a metastable behavior. A conservative estimate of the bulk concentration of $\mathrm{NaHCO}_{3}$ in the type-B-melt is about 2 mass $\%$, corresponding to about 1 mass $\% \mathrm{CO}_{2}$ or 1.36 mass $\% \mathrm{CO}_{3}{ }^{-2}$. The small nahcolite and zabuyelite-rich inclusions in quartz immediately adjacent to type-B melt inclusions can therefore be interpreted as formed by separation (necking) from a large type-B melt inclusion.

The metastable behavior of the fluid system of the type-B melt inclusions was also demonstrated during the Raman measurement. The Raman band at $1,360 \mathrm{~cm}^{-1}$ originally present, corresponding to the normal mode of vibration of the $\mathrm{HCO}_{3}{ }^{-}$, decrease rapidly during measurement, and at the same time the intensity of the $1,380 \mathrm{~cm}^{-1}$ carbonate band increases.

Some melt inclusions contain topaz crystals (Fig. 4b) with highly variable phase relationship between the volume of topaz crystals and the volume of the melt inclusion, implying that the topaz was accidentally co-trapped with the melt. Other inclusions contain small topaz crystals grown during quenching. Both observations show that topaz was stable at the crystal growth temperature of smoky quartz $\left(\approx 650^{\circ} \mathrm{C}\right)$. We note that topaz is a very rare mineral in the Königshain pegmatites, presumably, given the high fluorine concentration the 
primary topaz was replaced at lower temperatures by muscovite, referred to as gilbertite (a synonym or variety of muscovite).

Fluid inclusions in smoky quartz and other minerals

Thermometric results of some paragenetic minerals from miarolitic cavities in the Königshain granite are summarized in Table 3. Most of the fluid inclusions represent moderately concentrated solutions with $\mathrm{NaCl}$ as the main component. However, some inclusions also contain relative high concentrations of $\mathrm{Na}_{2} \mathrm{CO}_{3}$; values between 1.5 and 10 mass $\%$ were found. The variability in the composition can be explained, at least in part because the crystals examined came from different miarolitic cavities.

Homogenization temperatures of fluid inclusions around $380^{\circ} \mathrm{C}$ were found for some smoky quartz and schorl crystals. These data are the highest values for the two-phase fluid inclusions and imply the maximum trapping temperature for these inclusions, and thus the approximate growth temperature of the host crystals. Because some fluid inclusions homogenize with critical behavior, we can estimate the minimum pressure during the trapping of these inclusions to be about 235 bars, corresponding to a depth of about $0.9 \mathrm{~km}$. This corresponds very well to the depths of the Variscan granite intrusions in the Erzgebirge region (Thomas and Klemm 1997).

In contrast to the inclusions in Table 3, inclusions in the [11-1] planes in the large fluorite crystal (Fig. 3a, b) are multiphase fluid inclusions containing crystals, an aqueous phase, and a shrinkage bubble. With Raman spectroscopy, we identified quartz, albite, muscovite, clinochlore and ungarettiite. However, the melting temperatures of ice and hydrohalite in the "multiphase" inclusions are very constant, implying that the solid phases were not in equilibrium with the solution at the trapping of the fluid inclusions. There is also a great variability between the relative volumes of crystals to the enclosing inclusion. Both points suggest that these cannot be daughter phases, and represent minerals coexisting with the aqueous fluid and accidentally co-trapped. Because the density of the different solid mineral phases varies between 2 and $5 \mathrm{~g} / \mathrm{cm}^{3}$, there must be a relatively strong convection current within the miarolitic cavity which prevented the settling out of the coexisting crystals, or the viscosity of the mineral-forming fluid was high enough to prevent complete setting. The very rare two-phase fluid inclusions in the [111] planes give the same thermometric and cryometric data as the "multi-phase" inclusions. 
Magmatic versus hydrothermal fluorite

The magmatic or high-temperature fluorite is characterized by abundant small dispersed crystals of zircon, xenotime, and bastnäsite (see Fig 2b). The fluorite itself is relatively rich in yttrium $\left(5,125 \pm 1,000 \mathrm{ppm} \mathrm{Y}_{2} \mathrm{O}_{3}, \mathrm{n}=13\right)$ and the sum of the REE's is 3,360 $\pm 1,570 \mathrm{ppm}$. The heavy REE's are dominant. The Raman spectra of the magmatic fluorite are characterized by very strong fluorescence bands in the high-frequency range as observed in these samples. In strong contrast, the low-temperature fluorite is very $\mathrm{Y}$ and the REE poor, in each case below detection limit. Table 4 gives results for monazite, xenotime, bastnäsite and fluorite. In our view, these fluorite textures (Fig. 2b) are the result of lit-par-lit replacement.

The crystallization of fluorine and bastnäsite-(Ce) at magmatic conditions demonstrate that the mineral-forming melt or fluid was carbonate and fluorine-rich. Most of the cracks which transect the zircon, fluorite and quartz grains are filled with xenotime, bastnäsite-( $\mathrm{Ce})$ and a Th-rich carbonate phase (Fig. 2c).

\section{Composition of the graphic zircon in the graphic granite}

Table 5 gives the composition of zircons from the graphic granite. Using Th-Zr correlation, we can discriminat between two groups: $\mathrm{ThO}_{2}<0.09$ and $\mathrm{ThO}_{2}>0.09$ mass\%. Also included are data from two Hf-rich zircons attached as small separate grains on zircon glyphs. From Th-U-Pb analyses, we have estimated a chemical age (i.e., $\mathrm{U}-\mathrm{Th}$-total $\mathrm{Pb}$ isochron ages calculated for monazite, xenotime, and uraninite using an electron microprobe at $\mu \mathrm{m}$ scale) for the graphic granite of about 320 Ma using to the method of Rhede et al. (1996), which corresponds to the ${ }^{207} \mathrm{~Pb} /{ }^{206} \mathrm{~Pb}$ age of $315 \pm 6 \mathrm{Ma}$ of the Königshain granites determined using the single zircon evaporation method (Hammer et al. 1999).

The existence of graphic zircon demonstrates $\mathrm{Zr}$ saturation at the onset of crystallization of the melt-dominated pegmatite system. With further fractionation, the Hf content increases continuously up to values of 18 mass $\% \mathrm{HfO}_{2}$. This is consistent with the results obtained for the zircons from different pegmatite-forming melt patches (peraluminous vs. peralkaline melt) from Ehrenfriedersdorf (Thomas et al. 2006b) in which the Hf concentration increases from 2.4 to 15.1 mass \%. This tendency for Hf to behave differently in type-A and type-B melts, combined with their different density, viscosity, and therefore mobility, may be relevant to the problems with respect to $\mathrm{Hf}$ encountered in current pegmatite classification schemes (e.g., Černý and Ercit 2005). 


\section{Discussion}

\section{The boundary layer Question}

It is a basic premise of any melt inclusion study that the primary melt and fluid inclusion compositions represents the media in which the crystals grew, and thus provides a means of constraining natural melts. However, in recent years a suggestion has been made that the compositions noted in melt and fluid inclusions from pegmatites simply represent artefacts of a boundary layer effect (e.g., London 2008). Crystallization of a mineral will progressively deplete the melt adjacent to the growing crystal in elements contained in that crystal, and enrich it in elements that are incompatible. This effect will be controlled by the diffusion rate and crystal growth-rate. If a boundary layer is sufficiently thick, melt inclusions will sample only that layer. Although feasible in experimental systems, we would suggest that it is unlikely to be a significant factor in pegmatite formation on a number of grounds. One obvious corollary of the formation of a boundary layer is that its composition should be a function of the mineral the boundary layer forms adjacent to. Since for each mineral there would be different sets of compatible and incompatible elements, there should likewise be a specific boundary layer composition for a given mineral and melt. In distinct contrast, we observe that pegmatites containing coexisting type-A and type-B melt inclusions of corresponding compositions in more than one mineral from the same location have been found at Ehrenfriedersdorf, Zinnwald, Altenberg, Sadisdorf, and Pechtelsgrün, in Germany (Thomas et al. 2006a, b), Seixo Amarelo-Concalo in Portugal (unpublished), Bornholm in Denmark (in preparation). Also in evolved granites Zinnwald, Ehrenfriedersdorf, Greifensteine, Eibenstock, in Germany (Thomas et al. 2005; Webster and Thomas 2006), Slakovsky les in the Czech Republic, and Beauvoir in France (unpublished). In all of these cases, the compositions of type-A and type-B melt inclusions are dependent only on the temperature of trapping (i.e., how far the conjugate melts have evolved from the critical point, Thomas 2000), not the minerals in which they are found.

Published studies have demonstrated that boundary layer effects are minor in granitic systems (e.g., Lu et al. 1992, Thomas et al. 2002), and where present the effects can be readily detected, for example, by a direct relationship between inclusion size and composition. Given that the compositions of melt inclusions from Ehrenfriedersdorf and in other pegmatites have 
very low calculated densities and viscosities, diffusion and convection should eliminate boundary layer effects even more efficiently than in granitic melts.

As stated, the compositions of melt and fluid inclusions from pegmatites demonstrate melts with very low densities and viscosities; even if a boundary layer of such composition could form it should be displaced rapidly by gravity, tending to rapidly pond on the chamber roof, and being forced away from crystals growing deeper in the chamber. Also, given strong thermal contrasts, and exsolution of vapor phase (as indicated by primary fluid inclusions), convection should be very rapid and would tend to disrupt any boundary layer that may form.

Some pegmatite chambers are large, complex, 3D spaces crystallizing minerals that may project several meters into the chamber. It is therefore improbable that growing crystals would only trap "exotic" boundary layer compositions, without sometimes trapping "normal" silicate melt. However, melt inclusions in pegmatites are consistently of similar "exotic" compositions, or more rarely composites of two or more of these immiscible conjugate melts (e.g., Thomas et al. 2000, 2006a, 6b, 2008, in preparation).

Moreover, we would suggest that analogies to zone-refining and similar processes in the semiconductor industry should be taken with caution, since the processes are not robust and can easily be interfered with by processes and factors (convection, boiling, strong temperature and pressure fluctuations) that would be endemic in a convecting, bubbling, pegmatite chamber.

Taken together, the evidence supports the proposition that coexisting primary melt and fluid inclusion compositions reflect the composition of the media from which the host minerals crystallized.

\section{Evidence for conditions of crystallization at Königshain}

The coexistence of two different silicate melt inclusion types at the same temperature in several different minerals in the Königshain miarolitic pegmatites is convincing evidence of silicate melt-melt immiscibility, and the consequent development of two conjugate silicate melts. Moreover, this is consistent with results previously demonstrated from more conventional pegmatites (e.g., Thomas et al. 2000, 2006a, b, 2008). Since the two endmember compositions (type-A and type-B melts) are converging, and since the curve of the pseudobinary is very flat in the neighborhood of the critical temperature, it follows that the critical temperature is close to $700^{\circ} \mathrm{C}$. Moreover, the estimated water content at the critical composition (i.e., the $\mathrm{H}_{2} \mathrm{O}$ concentration at the point of convergence) is about 26 mass $\%$. 
These conditions correspond to the onset of melt-melt immiscibility, and probably the beginning of crystallization in the miarolitic cavity in the Königshain pegmatites. This can be compared to the Ehrenfriedersdorf pegmatite (Thomas et al. 2000,) where the solvus crest of the pseudobinary was shown to be at $3 \mathrm{kbar}, 720^{\circ} \mathrm{C}$ and $\sim 20$ mass $\% \mathrm{H}_{2} \mathrm{O}$.

The bulk water content of the melt inclusions is highly variable, values between 8 and 50 mass $\%$ were found in inclusions in close proximity. The coexistence of type-A, type-B inclusions across their whole range of compositions with vapor-rich fluid inclusions showing variable bubble volume, is evidence of a very dynamic, boiling melt-fluid system, and imply very low viscosities of the pegmatite-forming melts. Moreover, because the amounts of other volatiles, especially fluorine, are only moderate, and pressures relatively low, such low viscosities are only possible if enough water is present. In our view this is an essential observation. According to Mustart (1972), such high $\mathrm{H}_{2} \mathrm{O}$ concentrations at relative low pressure are only possible in peralkaline melts (see also Table 1). The calculated ASI data in Table 1 underlines this proposition. Furthermore, the primary pegmatite-forming initial melt must have also a very low density. Calculations using the model of Herzberg (1987) yield values of 1.8 to $2.0 \mathrm{~g} / \mathrm{cm}^{3}$ at $700^{\circ} \mathrm{C}$ and $2 \mathrm{kbar}$. This density contrast between the pegmatiteforming melt and the granite host (density $\sim 2.5 \mathrm{~g} / \mathrm{cm}^{3}$ ) and the very low viscosity (see Thomas et al. 2006b) enables the separation, flow and ascent of the intergranular melt. According to Audétat and Keppler (2004) the viscosity is in the order of $1 \mathrm{~Pa} . \mathrm{s}-$ a very large contrast to the host water-poor granite melt with a viscosity of $10^{4}-10^{5} \mathrm{~Pa}$.s or more.

The presence of melt inclusions in type- 2 smoky quartz shows that some melt phase remained present at temperatures below $573^{\circ} \mathrm{C}$, making the transition from melt- to fluiddominated stage somewhat obscure. The fluid-dominated stage is characterized by hydrothermal growth and re-crystallization of smoky quartz and feldspar, overgrown by colorless quartz and albite at lower temperatures. The homogenization temperatures of the water-clear albite and fluorite crystals $\left(\leq 165^{\circ} \mathrm{C}\right)$ terminate the hydrothermal main stage, and the one-phase fluid inclusions in stilbite-Ca crystals $\left(<50^{\circ} \mathrm{C}\right)$ indicate the very end stage.

The evidence from melt and fluid inclusions shows that the early minerals in the Königshain miarolitic pegmatite were crystallizing from a complex mixture of two silicate melts and a supercritical fluid. The characteristics of these phases (composition, and low density and viscosity) are not consistent with the silicate melts proposed in some other models of pegmatite formation (e.g., London 2008, and references therein); however, they are consistent with the characteristics of melt inclusions from other pegmatites (e.g., Ehrenfriedersdorf, Thomas et al. 2000; Elba, Thomas et al. 2008). The melt inclusion 
evidence points to the same, complex processes that formed other pegmatites, and clearly shows that the origin of miarolitic pegmatites cannot be reduced to a simple one-step process used by Černý and Ercit (2005) as definition for the miarolitic class of granitic pegmatites. In the view of Černý and Ercit (2005), miarolitic pegmatites are primary cavities resulting from trapping bubbles of an exsolved gas phase inside the parent pegmatite body. This model does not explain the coexistence of three mutually immiscible phases in the Königshain miarolitic pegmatite (type-A and type-B melts, and supercritical fluids).

\section{Chemistry of pegmatite crystallization}

In addition to temperature and pressure constraints, our study throws light on a very important point of the pegmatite genesis; the chemical characteristics of the pegmatiteforming melt at the beginning of crystallization. Before immiscible separation of the primary melt into two conjugate melts (type-A and type-B melts) the parental melt had a water-rich peralkaline bulk composition. After separation, both melts trapped in different inclusion types have strongly differing chemical characters, the type-A melts are strongly peraluminous and the type-B melts are strongly peralkaline. Being mutually immiscible, this strong chemical contrast could be maintained in the liquid phase, and thus trapped as melt inclusions, but with cooling, crystallization, and reaction with wall-rocks must eventually be lost.

Given their high mobility and peralkaline nature melt or fluid can move rapidly along fractures and grain boundaries and is thus an efficient agent for extraction of elements sitting at such boundaries (c/f Audétat and Keppler 2004). At larger scales, such migration can, under suitable conditions, form spanning networks (Candela and Blevin 1995, and references therein) and provide much enhanced flows.

Initially, the parental melt contains large amounts of dissolved $\mathrm{OH}^{-}$and $\mathrm{CO}_{3}{ }^{2-}$, however, as crystallization begins these change speciation and exsolve as $\mathrm{H}_{2} \mathrm{O}$ and $\mathrm{CO}_{2}$ resulting in an increase in volume, and thus pressure. We have found $\mathrm{CO}_{2}$-rich melt inclusions only in the free-grown smoky quartz crystals and from microscope observations (separate $\mathrm{CO}_{2}$ and $\mathrm{H}_{2} \mathrm{O}$ bubbles in quenched melt inclusion glass) it follows that reaction $\mathrm{CO}_{2}$ exsolution happens after the reaction $\mathrm{H}_{2} \mathrm{O}$ exsolution at slightly lower temperatures. The water-saturated pegmatite-forming melt starts crystallization at the wall of the pegmatite body and immediately begins second boiling and liquid immiscibility, forming a very dynamic meltfluid system. Evidence for such behavior comes from the two melt inclusion types (type-A and type-B), and syngenetic vapor-rich fluid inclusions observed in quartz of the graphic 
granite. This process is continuous as long as water-rich melts are present. The high concentration of $\mathrm{CO}_{2}$ as carbonate ion in the melt further suggests that the melt or fluid must be peralkaline, because the solubility of $\mathrm{CO}_{2}$ in felsic melts at low pressure is very low. The existence of nahcolite, zabuyelite and dawsonite determined with the Raman spectroscopy reinforce this point.

With cooling, the evolution of gas phases result in large volume changes and thus a pressure increase. However, since the mineral-forming media is compressible (due to the lowdense vapor-phase) and the miarolitic cavity can accommodate the tensile stress. With further cooling this "overpressure" is reduced to the hydrostatic pressure of about 235 bar corresponding to a depth of about 2,500 $\mathrm{m}$.

Another point to be noted is that because the "primary" pegmatite-forming fluid has a low density, and is of strongly peralkaline character, they will react until equilibrium is attained with the wall rock forming the graphic granite. Thus, not all the quartz and feldspar components are taken in with the peralkaline fluid, so the pegmatite-forming process can be considered as a coupled magmatic-high temperature-metasomatic process, connected with crystallization and re-crystallization. In this light, some observations of accumulative metasomatic re-crystallization (Kozlowski 2002) in some pegmatitic bodies (Strzegom massif) can be explained.

\section{The relationship of the Königshain miarolitic pegmatites to other pegmatites}

The location of the Königshain miarolitic pegmatites as small isolated pods within the much larger volume granite body, often without obvious interconnections, although generally associated with schlieren and late-magmatic jointing, precludes the possibility of the injection of a discrete external magmatic pulse. Rather, the evidence presented suggests the scavenging of a low-concentration residue from the larger volume of the host granite melt. The percolation of this residual melt via pathways on scales from grain-boundaries through to latemagmatic joints appears to have controlled the size and location of miarolitic bodies. Crystallization of these immiscible late melt fractions explains the features observed in the Königshain miarolitic pegmatites, the open space filled with large crystals, the exotic minerals found there, and the zoning, including the graphic granite rim. The crystallization in the miarolitic cavities is thus a combination of metasomatic reaction, magmatic crystallization and postmagmatic pneumatolitic-hydrothermal re-crystallization in a quasi-closed system. 
Thus, we would suggest that the Königshain miarolitic pegmatites represent an example of the permeability of shallow granitic bodies suggested by several Australian examples (summarized in Candela and Blevin 1995). These show small-scale ( $\mathrm{cm}$ - meter) pegmatites occurring as 3D linked networks, sometimes spanning tens to hundreds of meters, commonly in the apices of granitic intrusions. The intrusions in question commonly host mineralization (Sn-W or $\mathrm{Au}$ ) in their carapace or immediately adjacent host rocks. These linked miarolitic cavities, now filled with pegmatite, were used by Candela and Blevin (1995) to suggest strong fluid permeability in magma bodies. In effect, these linked miarolitic pegmatites are the drainage networks of late-magmatic melts and fluids. In a much larger granitic body, we could expect relatively larger volumes of residual melt to be available, so with sufficient permeability much larger melt pockets could form at the most favored nodes (as in the Ukrainian chamber pegmatites, see Pavlishin and Dovgyi 2007). However, other factors need to be considered, for example, the temperature of residual melt segregation. If the main granitic magma is permeable at a higher temperature the "drainage networks" required for melt extraction would tend to collapse under gravity, forcing the melt into the largest available melt pockets, and eliminating much evidence of the networks.

We would suggest that volatile-rich type-B melt inclusions can be considered, with some license, as microscopic proxies for miarolitic pegmatites in some high-level granite plutons such as Königshain. The viscosity of such fluid-rich melt is very low ( $1 \mathrm{~Pa} . \mathrm{s})$ and therefore such melt/fluid has a high mobility and can move rapidly into pressure sinks, where they may accumulate. Such inclusions have a central droplet of aqueous liquid with a vapor bubble, surrounded by a variable thickness rim of aluminosilicate glass deposited on the inclusion walls (Figs. 4c, d, 6b, d). On a larger scale, miarolitic pegmatites show similar features, and certainly trap type-B melts and mixtures with other phases.

In comparison to Thomas et al. 2000, 2006a, b, and several others, the results of this study will seem familiar. In a large range of granitic pegmatites of several different types, we are seeing remarkably similar melt inclusion, occurring in several different minerals in each pegmatite. Those inclusions also demonstrate consistent characteristics, including very high $\mathrm{H}_{2} \mathrm{O}$ concentration, very low viscosity and density (and thus high mobility) and extremely reactive compositions. We note that the Königshain miarolitic pegmatites possess many general pegmatite features such as very large crystals often growing into a cavity, internal zoning, graphic granite rims, and abundant exotic minerals not found, or very rare, in the host granite. However, we note a fundamental problem; the very properties that are so distinctive about pegmatite-forming melts ensure that they can only survive as melt or fluid inclusions. 
In open or quasi-open systems cooling and reaction will homogenize out the differences, so that they will not survive in outcrop scale. Nevertheless, at the time of pegmatite formation we have demonstrated a distinctive connection between pegmatites of several different classifications.

\section{Conclusions}

Melt and fluid inclusions in minerals of the miarolitic pegmatites in the Variscan Königshain granite demonstrate that the pegmatite-forming melts or fluids were, at the beginning of crystallization, already very water-rich (probably water-saturated), and peralkaline. Furthermore, the melts or fluids were enriched in some elements including $\mathrm{H}, \mathrm{Li}$, $\mathrm{Na}, \mathrm{K}, \mathrm{Rb}, \mathrm{Cs}, \mathrm{Be}, \mathrm{Ca}, \mathrm{B}, \mathrm{Al}, \mathrm{C}, \mathrm{Si}, \mathrm{P}, \mathrm{F}, \mathrm{Cl}$, the REE's, Zr, Hf, Mo, W, Th and U, all typical of pegmatites. The melts and fluids from which the Königshain miarolitic pegmatites formed were late-magmatic melt fractions, which segregated from the host granite, but which do not appear to have migrated significant distances. Moreover, the high carbonate concentrations, which increase in the melt-dominated stage with cooling are far in excess of the carbonate solubility possible in normal fractionated crystallization of evolved granite magma. Thus, the formation of the pegmatite-forming melt cannot be the result of a normal fractionated crystallization of evolved granite magma. Critically, the melt in the miarolitic cavities are primary, and not in the equilibrium with the host granite: Granite and pegmatite coexist; however, they are decoupled at a physicochemical level, liquidus undercooling (London 2008) cannot be maintained.

From our observations, the crystallization in the miarolitic cavities is thus a combination of metasomatic reaction, magmatic crystallization and postmagmatic pneumatolitichydrothermal re-crystallization in a quasi-closed system. Moreover, we suggest that the crystallization of the miarolitic pegmatite type is similar to the crystallization of other granite pegmatites (stockscheider and vein type) described from other places (Erzgebirge, Transbaikalia, etc.). The differences between these various types can be explained, in part, by the efficiency of the drainage networks, miarolitic pegmatites representing inefficient drainage of volatile-rich residual melt fractions, whereas larger pegmatites represent preferential filling of the most favored nodes in the drainage network.

\section{Acknowledgments}


The authors wish to express their appreciation to Mrs. H. Steiger for the performing of numerous high-pressure re-homogenization experiments and G. Berger for the preparation of numerous thick sections, both from the GFZ Potsdam. We thank D. Voznyak (Kiev, Ukraine) for the provision of important papers to problems of the crystallization in chamber pegmatites. We would like to thank Mr. W. Lange (Zittau) for fruitful discussion in the granite quarry "Melaune" in the Königshain Mountain and Mr. Maiwald from the ProStein GmbH \& Company $\mathrm{KG}$ for the permission to visit the quarry.

The Editor and two anonymous reviewers are thanked for their helpful suggestions.

\section{References}

Åmli R, Griffin WL (1975) Microprobe analysis of REE minerals using empirical correction factors. Am Mineral 60: 599-606

Armstrong JT (1991) Quantitative elemental analysis of individual microparticles with electron beam instruments. In: Electron probe quantification, KFJ Heinrich and DE Newbury, Eds. Plenum Press, New York, pp 261-315

Audétat A, Keppler H (2004) Viscosity of fluids in subduction zones. Science 303: 513-516.

Bakker RJ (2003) Package FLUIDS 1. Computer programs for analysis of fluid inclusion data and for modelling bulk fluid properties. Chem Geol 194: 3-23

Beus AA (1966) Geochemistry of beryllium and genetic types of beryllium deposits. Freeman and Company, San Francisco

Borisenko AS (1974) Determination of sodium carbonates and bicarbonates in solutions of gas-liquid inclusions in minerals. Akad Nauk SSSR Dokl 214: 917-920 (in Russian)

Borisenko AS (1977) Cryometric technique applied to studies of the saline composition of solution in gaseous fluid inclusions in minerals. Geologija i Geofizika, AN SSSR, SO, 8: 16-27 (in Russian)

Brotzen O (1959) Outline of mineralization in zoned granitic pegmatites. Geol För Förh 81: 198.

Burnham CW (1979) The importance of volatile constituents. In: The evolution of the ignous rocks: fiftieth anniversary perspectives. (HS Yoder Jr., ed). Princeton University Press, Princeton, pp 439-482

Candela PA, Blevin PL (1995) Do some miarolitic granites preserve evidence of magmatic volatile phase permeability? Econ Geol 90: 2310-2316 
Černý P, Ercit TS (2005) The classification of granitic pegmatites revisited. Can Mineral 43: 2005-2026.

Downs RT (2006) The RUFF ${ }^{\mathrm{TM}}$ project: an integrated study of the chemistry, crystallography, Raman and infrared spectroscopy of minerals. Program and abstracts of the $19^{\text {th }}$ general meeting of the international mineralogical association in Kobe, Japan. O03-13

Ebert H (1943) Das granitische Grundgebirge der östlichen Lausitz. Hirzel, Leipzig

Eidam J, Götze J (1991) The granitic massif of Königshain-Arnsdorf (Lusatian Anticlinal Zone) - An example of a reversely zoned pluton. Chem Erde 51: 55-71

Förster HJ, Tischendorf G, Rhede D, Naumann R, Gottesmann B, Lange W (2005) Cs-rich lithium micas and Mn-rich lithian siderophyllite in miarolitic NYF pegmatites of the Königshain granite, Lausitz, Germany. N Jb Miner Abh 182: 81-93

Hammer J, Eidam J, Röber B, Ehling BC (1999) Prävariscischer und variscischer granitoider Magmatismus am NE-Rand des Böhmischen Massivs - Geochemie und Petrogenese. Z Geol Wiss 27: 401-415

Hecht L, Thuro K, Plinninger R, Cuney M (1999): Mineralogical and geochemical characteristics of hydrothermal alteration and episyenitization in the Königshain granites, northern Bohemian Massif, Germany. Int J Earth Sci 88: 236-252.

Herzberg CT (1987) Magma density at high pressure: part 1. The effect of composition on the elastic properties of silicate liquids. In: Mysen B (ed), Magmatic processes: physicochemical principles, special publication, Vol. 1. The Geochemical Society, pp 2546.

Janeczek J (2007) Intragranitic pegmatites of the Strzegom-Sobotka massif - an overview. Granitoids in Poland, AM Monograph No, 1: 193-201

Lange W, Tischendorf G, Krause U (2004) Minerale der Oberlausitz. Oettel, Görlitz-Zittau London D (1992) The application of experimental petrology to the genesis and crystallization of granitic pegmatites. Can Mineral 30: 499-540

London D (2004) Geochemistry of alkali and alkaline earth elements in ore-forming granites, pegmatites, and rhyolites. In: Linnen R, Sampson (eds) Rare-element geochemistry of ore deposits: Mineralogical Association of Canada Short Course Notes 17: 17-43

London, D. (2008) Pegmatites. Can Mineral, Special Publication 10

Lu FQ, Anderson AT, Davis AM (1992) Melt inclusions and crystal-liquid separation in rhyolitic magma of the Bishop Tuff. Contrib Mineral Petrol 110: 113-120

Makarov SZ (1933) Isotherme Löslichkeit und Eis-Feld des ternären Systems $\mathrm{Na}_{2} \mathrm{CO}_{3}-\mathrm{NaCl}$ $\mathrm{H}_{2} \mathrm{O}$. Z Allg Chemie 3: 234-248 (in Russian) 
Möbus G, Lindert W (1967) Das Granitmassiv von Königshain bei Görlitz (Oberlausitz). Abh Dt Akad Wiss, Kl Bergbau, Hüttenwesen und Montangeologie 1: 81-160

Mustart DA (1972) Phase relations in the peralkaline portion of the system $\mathrm{Na}_{2} \mathrm{O}-\mathrm{Al}_{2} \mathrm{O}_{3}-$ $\mathrm{SiO}_{2}-\mathrm{H}_{2} \mathrm{O}$. Dissertation, Stanford University, USA

Nývlt J (1977) Solid-liquid phase equilibria. Elsevier, Amsterdam

Oliver BG, Davis AR (1973) Vibrational spectroscopic studies of aqueous alkali metal bicarbonate and carbonate solutions. Can J Chem 51: 698-702

Pavlishin V, Dovgyi SA (2007) Mineralogy of the Volynian chamber pegmatites, Ukraine. Mineralogical Almanac, EKOST Association, Moscow, Ocean Pictures, Littleton

Rhede D, Wendt I, Förster HJ (1996) A three-dimensional method for calculating independent chemical U/Pb- and Th/Pb-ages of accessory minerals. Chem Geol 130: 247-253

Roeder PL (1985) Electron-microprobe analysis of minerals for rare-earth elements: use of calculated peak overlap corrections. Can Mineral 23: 263-271

Sirbescu ML, Nabelek PI (2003a) Crustal melts below $400^{\circ} \mathrm{C}$. Geology 31: 685-688

Sirbescu ML, Nabelek P (2003b) Dawsonite: an inclusion mineral in quartz from the Tin Mountain pegmatite, Black Hills, South Dakota. Am Mineral 88: 1055-1060

Thomas R (2000) Determination of water contents of granite melt inclusions by confocal laser Raman microprobe spectroscopy. Am Mineral 85: 868 - 872

Thomas R, Davidson P (2006) Progress in the determination of water in glasses and melt inclusions with Raman spectroscopy: a short review. Z Geol Wiss Berlin 34: 159-163

Thomas R, Klemm W (1997) Microthermometric study of silicate melt inclusions in Variscan granites from SE Germany: Volatile content and entrapment conditions. J Petrol 38: 17531765

Thomas R, Webster JD, Heinrich W (2000) Melt inclusions in pegmatite quartz: complete miscibility between silicate melts and hydrous fluids at low pressure. Contrib Mineral Petrol 139: 394-401

Thomas JB, Bodnar RJ, Shimizu N, Chesner C (2002) The boundary layer problem and the reliability of melt inclusions as petrogenetic monitors: evidence from melt inclusions in zircon, allanite, plagioclase and quartz, In: De Vivo B, Bodnar RJ (eds) Melt inclusions: methods, applications and problems. De Frede Editore, Napoli, pp 205-209.

Thomas R, Förster HJ, Heinrich W (2003) The behaviour of boron in a peraluminous granitepegmatite system and associated hydrothermal solutions: a melt and fluid-inclusion study. Contrib Mineral Petrol 144: 457-472

Thomas R, Förster HJ, Rickers K, Webster JD (2005) Formation of extremely F-rich hydrous 
melt fractions and hydrothermal fluids during differentiation of highly evolved tin-granite magmas: a melt/fluid-inclusion study. Contrib Mineral Petrol 148: 582-601

Thomas R, Webster JD, Davidson P (2006a) Understanding pegmatite formation: The melt and fluid inclusion approach. Melt inclusion in Plutonic rocks, MAC Short Course 36, Chap. 9, pp 189-210

Thomas R, Webster JD, Rhede D, Seifert W, Rickers K, Förster HJ, Heinrich W, Davidson P (2006b) The transition from peraluminous to peralkaline granitic melts: evidence from melt inclusions and accessory minerals. Lithos 91: 137-149

Thomas R, Davidson P, Hahn A (2008) Ramanite-(Cs) and ramanite-(Rb): New cesium and rubidium pentaborate tetrahydrate minerals identified with Raman spectroscopy. Am Mineral 93: 1034-1042

Veksler I, Thomas R (2002) An experimental study of B-, P- and F-rich synthetic granite pegmatite at 0.1 and 0.2 GPa. Contrib Mineral Petrol 143: 673-683

Voznyak DK, Matyash IV, Brick AB, Larikov AL, Mazykin VV (1984) On formation of the honeycomb quartz: ESR study. Geochimija 4: 534-540 (in Russian)

Webster JD, Thomas R (2006) Silicate melt inclusions in felsic plutons: a synthesis and review. MAC Short Course Vol. 36, Chap. 8, pp 165-188

Witzke T, Giesler T (2001) Neufunde aus Sachsen (VII): Bazzit, Bertrandit, euxenite-(Y), Powellit und andere aus dem Königshainer Granit in der Lausitz. Lapis 26: 43-48 


\section{Figures}

\section{Fig. 1}

Simplified geological map of the Königshain-Arnsdorf granite massif (Lusatian Anticlinal zone) based on Eidam and Götze (1991) with the sample locations

\section{Fig. 2}

a BSE image of crystals of zircon (white laths) intergrown in microcline (dark matrix) of the graphic granite, Königshain, E Saxony/Germany. A small fluorite crystal is attached to each zircon. b BSE image of a zircon crystal $(Z r n)$ in graphic granite with a large fluorite grain $(F l)$ and quartz $(Q t z)$. The small grey crystals in fluorite are zircon, xenotime, bastnäsite- $(C e)$ and fluocerite- $(\mathrm{Ce})$. $\mathbf{c}$ Channels and crack in the quartz grain in $\mathbf{b}$ (upper right), filled with xenotime, bastnäsite- $(\mathrm{Ce})$ and a Th-rich carbonate phase (bundle crystals in the centre of xenotime). d Detail from b zircon crystal ( $\mathrm{Zrn})$ and bastnäsite (Bas) in fluorite (Fl).

\section{Fig. 3}

a Fluid inclusions in the [11-1] planes of fluorite with accidentally co-trapped solid phases (quartz, albite, orthoclase, muscovite, clinochlore and ungarettiite). b Details of a single fluid inclusion from the [11-1] plan: Ab - albite, Ms - muscovite, Or - orthoclase, Qtz - quartz, V - vapor bubble. c Fluid inclusion in the [111] plane of the same crystal from Fig. 5a.

\section{Fig. 4}

a Water-rich type-A melt inclusion in graphic quartz, re-homogenized at $700^{\circ} \mathrm{C}$ and $3 \mathrm{kbar}, \mathrm{V}$ - vapor, $\mathrm{Fl}$ - aqueous liquid, $\mathrm{G}$ - glass. b Melt inclusion in smoky quartz with a $\mathrm{CO}_{2}$-rich bubble formed during quenching, $\mathrm{CO}_{2}-\mathrm{V}-\mathrm{CO}_{2}$ vapor, $\mathrm{CO}_{2}-\mathrm{L}$ - liquid $\mathrm{CO}_{2}, \mathrm{Fl}$ - aqueous liquid, G - glass, Toz - Topaz. c Water-rich type-B melt inclusion in a smoky quartz crystal, re-homogenized at $700^{\circ} \mathrm{C}$ and $2 \mathrm{kbar}, \mathrm{G}$ - glass, $\mathrm{V}$ - vapor, $\mathrm{Fl}$ - aqueous liquid, $\mathrm{CO}_{2}-\mathrm{F}-$ liquid $\mathrm{CO}_{2}, \mathrm{CO}_{2}-\mathrm{V}-\mathrm{CO}_{2}$ vapor. d Water-rich type-B melt inclusion in a smoky quartz crystal, re-homogenized at $700^{\circ} \mathrm{C}$ and $2 \mathrm{kbar}, \mathrm{V}$ - vapor, $\mathrm{Fl}$ - aqueous liquid, $\mathrm{G}$ - glass.

\section{Fig. 5}

a Section of a smoky quartz crystal from the Königshain pegmatite with three different zones: 1- cloudy base zone, 2 - cellular quartz zone, and 3 - a small, sharp zone of colorless quartz, poor in fluid inclusions. b A cell from the cellular quartz zone, such cells are formed from fluid inclusions arranged subparallel to the cell walls.

\section{Fig. 6}

Type-B-melt inclusions in smoky quartz, a and c show two melt inclusions before the rehomogenization; $\mathbf{b}$ and $\mathbf{d}$ the same inclusions after re-homogenisation at $650{ }^{\circ} \mathrm{C}$ and $2 \mathrm{kbar}$. Vvapor, F1 -fluid phase, G1 - inclusion glass (matrix glass), G2 - second very water-rich glass, formed by liquid-liquid immiscibility 


\section{Fig. 7}

a Type-A melt inclusion in smoky quartz $(Q t z)$ composed from glass $(G)$ and a decrepitated bubble $(V)$. $\mathbf{b}$ BSE image of a homogenized type-A melt inclusion in the same smoky quartz crystal ( $\mathrm{G}$-glass).

\section{Fig. 8}

a Raman spectra in the high-frequency range of a water-rich type-B melt inclusion in smoky quartz from Königshain, immediately after re-homogenization at $650^{\circ} \mathrm{C}$ and $1 \mathrm{kbar}$ using the rapid-quench technique. Total water content $\left(\mathrm{H}_{2} \mathrm{O}_{\mathrm{T}}\right)$ is between 32 and 36 mass $\%$ for the typeB glass. Gaussian deconvolution gives three main components centered at 3,297, 3,453, and $3,560 \mathrm{~cm}^{-1}$. b However, the glass-like type-B melt phase is unstable, and after a few hours, or during intensive Laser excitation the metastable glass disassociates at room temperature into a stable aluminosilicate glass, a water-rich liquid and a vapor phase, forming the characteristic type-B melt inclusion. At room temperature this aluminosilicate glass contain now only 13.4 \pm 0.4 mass $\% \mathrm{H}_{2} \mathrm{O}_{\mathrm{T}}$ and is characterized by a strong increase of the asymmetry of the Raman band, now with the main component at $3,550 \mathrm{~cm}^{-1}$.

\section{Tables}

\section{Table 1}

Electron microprobe analysis of large melt inclusions in graphic quartz (columns 2-4) from a miarolitic pegmatite in the Königshain granite: re-homogenized at $700^{\circ} \mathrm{C}$ and $3 \mathrm{kbar}$ in 20 hours, and small melt and gel-like inclusions in smoky quartz, crystallized at a temperature $\leq 570^{\circ} \mathrm{C}$, re-homogenized at $700^{\circ} \mathrm{C}$ and $2 \mathrm{kbar}$ in 20 hours; oxides in mass $\%$

\section{Table 2}

Calculation of the melt compositions (in mass\%) of the type-A and type-B pegmatite-forming melts from the estimated volume percentages of the main phases (muscovite, dawsonite, calcite and carbonate-rich solution) in the two inclusion types.

\section{Table 3}

Fluid inclusions in paragenetic minerals: thermometric and cryometric results.

\section{Table 4}

Chemical composition of fluorite, fluocerite, bastnäsite, monazite, xenotime and an unnamed Ce- and Th-rich mineral phase; oxides in mass \%

\section{Table 5}

Composition of zircon crystallized from graphic granite from miarolitic pegmatites from the Königshain granite (E Germany); oxides in mass\% 
Table 1 Electron microprobe analysis of large melt inclusions in graphic quartz (columns 2-4) from a miarolitic pegmatite in the Königshain granite

\begin{tabular}{|c|c|c|c|c|c|c|c|}
\hline & \multicolumn{3}{|c|}{ Graphic quartz } & \multicolumn{4}{|c|}{ Smoky quartz } \\
\hline & \multirow[t]{2}{*}{ Glass } & \multirow{2}{*}{$\begin{array}{c}\text { Glass, recalculated to } \\
18.4 \text { mass } \% \mathrm{H}_{2} \mathrm{O}\end{array}$} & \multirow{2}{*}{$\begin{array}{c}\text { Adjacent } \\
\text { type-B melt \# }\end{array}$} & \multirow{2}{*}{$\begin{array}{l}\text { Type-A melt } \\
\text { inclusions }\end{array}$} & \multicolumn{2}{|c|}{ Type-B melt inclusions } & \multirow{2}{*}{ Gel-like inclusion } \\
\hline & & & & & Glass part & $\begin{array}{c}\text { Bulk } \\
\text { composition } \dagger \dagger\end{array}$ & \\
\hline $\mathrm{SiO}_{2}$ & $64.4 \pm 1.8$ & 58.15 & 47.1 & 66.80 & 75.70 & 49.94 & $19.2^{*}$ \\
\hline $\mathrm{TiO}_{2}$ & $0 . \overline{02}$ & 0.02 & - & 0.02 & 0.04 & 0.03 & 0.2 \\
\hline $\mathbf{A l}_{2} \mathbf{O}_{3}$ & $12.9 \pm 0.3$ & 11.65 & 8.9 & 14.90 & 13.53 & 8.92 & - \\
\hline $\mathrm{FeO}$ & $1.6 \pm 0.2$ & 1.44 & - & 0.12 & 0.20 & 0.13 & - \\
\hline MnO & $0.08 \pm 0.02$ & 0.07 & - & 0.05 & 0.10 & 0.06 & - \\
\hline MgO & $0 . \overline{0}$ & 0.01 & - & d.l & 0.02 & 0.01 & - \\
\hline $\mathrm{CaO}$ & $0.19 \pm 0.01$ & 0.17 & d.l. & 0.82 & 0.44 & 0.29 & 7.1 \\
\hline $\mathbf{L i}_{2} \mathbf{O} \dagger$ & $1 . \overline{4}$ & 1.26 & 1.1 & - & - & - & - \\
\hline $\mathrm{Na}_{2} \mathrm{O} \#$ & $3.94 \pm 0.23$ & 3.56 & 5.8 & 2.53 & 3.44 & 3.31 & 7.3 \\
\hline $\mathbf{K}_{2} \mathbf{O}$ & $4.12 \pm 0.20$ & 3.72 & 2.4 & 2.90 & 3.57 & 3.71 & 7.1 \\
\hline $\mathbf{R} \mathbf{b}_{2} \mathbf{O}$ & $0.25 \pm 0.01$ & 0.22 & 0.2 & 0.11 & 0.21 & 0.14 & - \\
\hline $\mathrm{Cs}_{2} \mathrm{O}$ & $0.12 \pm 0.01$ & 0.11 & 0.09 & 0.06 & 0.04 & 0.02 &.- \\
\hline $\mathbf{F}$ & $2.28 \pm 0.05$ & 2.06 & 1.4 & 0.82 & 0.01 & 0.01 & - \\
\hline Cl & $0 . \overline{01}$ & 0.01 & 1.7 & 0.04 & 0.05 & 0.38 & - \\
\hline $\mathbf{P}_{2} \mathbf{O}_{5}$ & 0.01 & 0.01 & - & - & - & - & - \\
\hline $\mathrm{CO}_{3}{ }^{2-}$ & - & - & $1.2 \S$ & - & - & 3.11 & - \\
\hline Sum & 89.73 & 82.46 & 69.89 & 89.17 & 97.35 & 70.06 & 40.9 \\
\hline Sum $\ddagger$ & 88.77 & 81.60 & 68.92 & 88.82 & 97.33 & 69.97 & \\
\hline $\mathrm{H}_{2} \mathrm{O}$-calculated & 11.23 & 18.40 & $30.7 \S \S$ & 11.2 & 2.7 & 30.03 & 59.1 \\
\hline $\mathrm{H}_{2}$ O-Raman & $10.1 \pm 0.25$ & $18.4 \pm 0.8$ & 32 & $11.4 \pm 0.5(n=10)$ & 1.7 & - & - \\
\hline ASI & $0.79 \pm 0.24$ & & 0.55 & 1.68 & 1.29 & 0.88 & - \\
\hline n & $\overline{6}$ & & 3 & 3 & 2 & & 1 \\
\hline
\end{tabular}

Melt inclusion in graphic quartz, re-homogenized at $700^{\circ} \mathrm{C}$ and $3 \mathrm{kbar}$ in $20 \mathrm{~h}$, and small melt and gel-like inclusions in smoky quartz, crystallized at a temperature $\leq 570^{\circ} \mathrm{C}$, rehomogenized at $700^{\circ} \mathrm{C}$ and $2 \mathrm{kbar}$ in $20 \mathrm{~h}$; oxides in mass\%

ASI - Alumina Saturation Index - molar ratio $\left[\mathrm{Al}_{2} \mathrm{O}_{3} /\left(\mathrm{CaO}+\mathrm{Li}_{2} \mathrm{O}+\mathrm{Na}_{2} \mathrm{O}+\mathrm{K}_{2} \mathrm{O}+\mathrm{Rb}_{2} \mathrm{O}+\mathrm{Cs}_{2} \mathrm{O}\right)\right]$; $\mathrm{n}$ - analyzed melt inclusions

$\dagger$ Estimated according to London (2004); $¥$ Fluorine and chlorine corrected sum; \# Due to the high water concentration the value for $\mathrm{Na}_{2} \mathrm{O}$ is probably underestimated due to Namigration during analysis; $\S$ Determined from the melting temperature of nahcolite in the fluid phase of some type- $\mathrm{B}$ melt inclusion $\left(\mathrm{t}_{\mathrm{S}}=106.2^{\circ} \mathrm{C}\right.$ )

* Primary 69.0 mass\% $\mathrm{SiO}_{2}$ - recalculated to $\mathrm{CaSiO}_{3}, \mathrm{Na}_{2} \mathrm{SiO}_{3}$ and $\mathrm{K}_{2} \mathrm{SiO}_{3}$, the difference results from $\mathrm{SiO}_{2}$ taken from the inclusion wall by reaction during re-homogenization $\S \S$ This is a very conservative estimate, and the real value is probably much higher and the other values proportionally lower

†† Model composition, calculated using 50 vol\% glass (column 6) and 50 vol\% solution with $7 \mathrm{mass}_{2} \mathrm{~K}_{2} \mathrm{CO}_{3}, 4.2 \mathrm{mass}^{2} \mathrm{Na}_{2} \mathrm{CO}_{3}, 2 \mathrm{mass} \% \mathrm{NaCl}$ 
Table 2 Calculation of the melt compositions (in mass\%) of the type-A and type-B pegmatite-forming melts in type 2 smoky quartz, from the estimated volume percentages of the main phases in the two inclusion types.

\begin{tabular}{|c|c|c|}
\hline & Type-A melt inclusions & Type-B melt inclusions \\
\hline $\mathrm{CO}_{2}$ & 6.77 & 7.02 \\
\hline $\mathrm{SiO}_{2} *$ & 63.57 & 45.00 \\
\hline $\mathbf{A l}_{2} \mathbf{O}_{3}$ & 16.61 & 15.02 \\
\hline $\mathrm{Na}_{2} \mathrm{O}$ & 4.45 & 6.03 \\
\hline $\mathbf{K}_{2} \mathbf{O}$ & 2.85 & 5.95 \\
\hline $\mathrm{CaO}$ & 0.57 & 0.96 \\
\hline $\mathrm{H}_{2} \mathrm{O}$ & 5.18 & 18.78 \\
\hline $\mathrm{Cl}$ & - & 1.24 \\
\hline Sum & 100 & 100 \\
\hline ASI & 1.451 & 0.829 \\
\hline \multicolumn{3}{|c|}{ 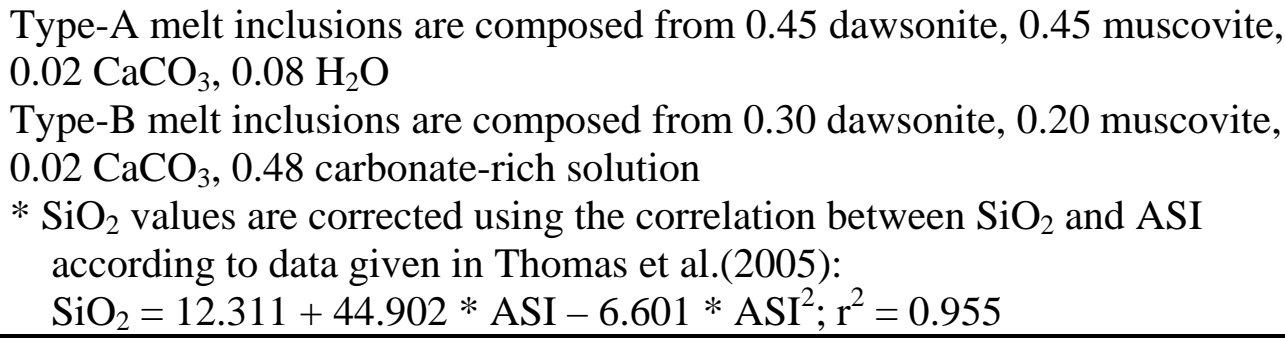 } \\
\hline
\end{tabular}


Table 3 Fluid inclusions in paragenetic minerals: Thermometric and cryometric results

\begin{tabular}{|c|c|c|c|c|c|c|c|c|}
\hline Mineral & $\begin{array}{c}\text { Sample } \\
\text { origin }\end{array}$ & $\begin{array}{c}\text { Th } \pm 1 \sigma \\
\left({ }^{\circ} \mathrm{C}\right)\end{array}$ & System & $\begin{array}{c}\operatorname{Tm}(h h) \pm 1 \sigma \\
\left({ }^{\circ} \mathrm{C}\right)\end{array}$ & $\begin{array}{c}\operatorname{Tm}(\text { ice }) \pm 1 \sigma \\
\left({ }^{\circ} \mathrm{C}\right)\end{array}$ & $\begin{array}{c}\mathrm{NaCl} \\
\text { eq. } \mathrm{mass} \% \pm 1 \sigma\end{array}$ & $\begin{array}{c}\mathrm{CaCl}_{2} \\
\text { eq. } \operatorname{mass} \% \pm 1 \sigma\end{array}$ & $\mathbf{m , n}$ \\
\hline Fluorite * & 3 & $165 \pm 1$ & $\mathrm{H}_{2} \mathrm{O}-\mathrm{NaCl}-\mathrm{CaCl}_{2}$ & -23.7 & -7.9 & 10.9 & 0.8 & 50,10 \\
\hline Fluorite & $1,2,3$ & $167 \pm 30$ & $\mathrm{H}_{2} \mathrm{O}-\mathrm{NaCl}-\mathrm{CaCl}_{2}$ & $-31.5 \pm 2.0$ & $-5.2 \pm 1.2$ & $2.1 \pm 0.4$ & $6.7 \pm 1.0$ & 147,10 \\
\hline Albite-core & 2 & $\geq 300$ & $\mathrm{H}_{2} \mathrm{O}-\mathrm{NaCl}$ & - & $-1 \overline{7} .5$ & 20.8 & & 5,2 \\
\hline Albite-core & 2 & $2 \overline{44} \pm 9$ & $\mathrm{H}_{2} \mathrm{O}-\mathrm{NaCl}$ & - & -4.5 & 7.2 & & 9,2 \\
\hline Albite & 2 & $207 \pm 6$ & $\mathrm{H}_{2} \mathrm{O}-\mathrm{NaCl}-\mathrm{CaCl}_{2}$ & -29.5 & -5.5 & 2.6 & 6.6 & 21,10 \\
\hline Albite-rim & $1,2,3$ & $178 \pm 9$ & $\mathrm{H}_{2} \mathrm{O}-\mathrm{NaCl}-\mathrm{CaCl}_{2}$ & -24.5 & -6.5 & 9.0 & 1.0 & 60,8 \\
\hline \multirow[t]{2}{*}{ Schorl † } & 1 & $372+12$ & $\mathrm{H}_{2} \mathrm{O}-\mathrm{NaCl}-\mathrm{CaCl}_{2}$ & -30.5 & -17.5 & 5.0 & 14.6 & 10,5 \\
\hline & & & & $\begin{array}{c}\mathrm{Te} \\
\left({ }^{\circ} \mathrm{C}\right) \\
\end{array}$ & $\begin{array}{c}\mathrm{Tm} \text { (ice) } \pm 1 \sigma \\
\left({ }^{\circ} \mathrm{C}\right)\end{array}$ & $\begin{array}{c}\mathrm{NaCl} \\
\text { eq. } \mathrm{mass} \%+1 \sigma\end{array}$ & $\begin{array}{c}\mathrm{Na}_{2} \mathrm{CO}_{3} \ddagger \\
\text { eq. } \text { mass } \%+1 \sigma \\
\end{array}$ & \\
\hline Fluorite & 3 & $315 \pm 5$ & $\mathrm{H}_{2} \mathrm{O}-\mathrm{NaCl}-\mathrm{Na}_{2} \mathrm{CO}_{3}$ & -21.9 & -4.1 & 4.2 & 4.4 & 5,10 \\
\hline Smoky quartz (I) & 3 & $387 \pm 18$ & $\mathrm{H}_{2} \mathrm{O}-\mathrm{NaCl}-\mathrm{Na}_{2} \mathrm{CO}_{3}$ & -21.3 & $-3.4 \pm 0.1$ & 2.7 & 4.8 & 14,14 \\
\hline Smoky quartz (I) & 3 & $382 \pm 5$ & $\mathrm{H}_{2} \mathrm{O}-\mathrm{NaCl}-\mathrm{Na}_{2} \mathrm{CO}_{3}$ & -20.6 & $-3.2 \pm 0.2$ & $2.4 \pm 0.4$ & $4.9 \pm 0.2$ & 22,22 \\
\hline \multirow[t]{2}{*}{ Smoky quartz (I) } & 1,2 & $375 \pm 6 \#$ & $\mathrm{H}_{2} \mathrm{O}-\mathrm{NaCl}$ & -21.2 & $-2.4 \pm 0.3$ & $4.0 \pm 0.5$ & & 10,9 \\
\hline & 3 & $349 \pm 17$ & $\mathrm{H}_{2} \mathrm{O}-\mathrm{NaCl}-\mathrm{Na}_{2} \mathrm{CO}_{3}$ & -21.5 & -5.5 & 6.7 & 3.7 & 54,6 \\
\hline \multirow{2}{*}{ Smoky quartz (I) } & 1 & $380 \pm 2$ & $\mathrm{H}_{2} \mathrm{O}-\mathrm{NaCl}-\mathrm{Na}_{2} \mathrm{CO}_{3}$ & -21.3 & -3.7 & 3.4 & 4.6 & 15,5 \\
\hline & 3 & $347 \pm 10$ & $\mathrm{H}_{2} \mathrm{O}-\mathrm{NaCl}-\mathrm{Na}_{2} \mathrm{CO}_{3}$ & -20.9 & -5.3 & 6.4 & 3.8 & 10,5 \\
\hline Smoky quartz (II) & 2 & $288 \pm 10$ & $\mathrm{H}_{2} \mathrm{O}-\mathrm{NaCl}-\mathrm{Na}_{2} \mathrm{CO}_{3}$ & -21.4 & $-5.4 \pm 0.6$ & $6.5 \pm 1.0$ & $3.7 \pm 0.3$ & 22,30 \\
\hline Smoky quartz (II) & 3 & $278 \pm 5$ & $\mathrm{H}_{2} \mathrm{O}-\mathrm{NaCl}-\mathrm{Na}_{2} \mathrm{CO}_{3}$ & -21.4 & $-4.9 \pm 0.4$ & $5.7 \pm 0.7$ & $4.0 \pm 0.2$ & 10,8 \\
\hline Smoky quartz (III) & 2,3 & $197 \pm 26$ & $\mathrm{H}_{2} \mathrm{O}-\mathrm{NaCl}-\mathrm{Na}_{2} \mathrm{CO}_{3}$ & -23.9 & $-3.3 \pm 1.6$ & 1 to 5.7 & $4.8 \pm 1.0$ & 180,10 \\
\hline Smoky quartz (III) & 3 & $183 \pm 5$ & $\mathrm{H}_{2} \mathrm{O}-\mathrm{NaCl}-\mathrm{Na}_{2} \mathrm{CO}_{3}$ & -20.7 & -3.3 & 2.6 & $\overline{4.8}$ & 15,10 \\
\hline Albite (transparent) & 2 & $213+3$ & $\mathrm{H}_{2} \mathrm{O}-\mathrm{NaCl}-\mathrm{Na}_{2} \mathrm{CO}_{3}$ & -21.4 & -6.7 & 8.5 & 3.2 & 10,10 \\
\hline
\end{tabular}

Sample origin: 1) Firstensteinbruch (Firstenstein quarry) near Königshain, 2) Tiefer Bruch (Depth quarry) near Döbschütz, 3) Steinbruch (quarry) near Hilbersdorf

Th - homogenization temperature, $\sigma$ - standard deviation

Te - temperature of eutectic melting

Tm (hh) - melting temperature of hydrohalite

Tm (ice) - melting temperature of ice

$\mathrm{m}, \mathrm{n}$ - number of measured inclusions: $\mathrm{m}$ - homogenization, $\mathrm{n}$ - cryometry

* large fluorite crystal (main sample)

\# homogenization with critical behavior

$\dagger$ According to Raman spectroscopy

$\ddagger$ According to Raman spectroscopy the estimated bulk carbonate concentration is $\sim 2.7 \mathrm{~mol} / \mathrm{l}$ - this means, beside $\mathrm{Na}_{2} \mathrm{CO}_{3}$ other readily soluble carbonates $\left(\mathrm{K}_{2} \mathrm{CO}_{3}, \mathrm{Rb}_{2} \mathrm{CO}_{3}\right.$,

$\mathrm{Cs}_{2} \mathrm{CO}_{3}$ ) must be present. As an example, the solubility of $\mathrm{K}_{2} \mathrm{CO}_{3}$ and $\mathrm{Cs}_{2} \mathrm{CO}_{3}$ in water are at $20^{\circ} \mathrm{C} 52.5$ and 72.3 mass $\%$ respectively. 
Table 4 Chemical composition of fluorite, fluocerites and bastnäsite from Königshain pegmatites, oxides in mass\%

\begin{tabular}{|c|c|c|c|c|c|c|c|}
\hline & Fluorite-I & Fluocerite-(Ce) & Bastnäsite-(Ce) & Monazite-(Ce) & Xenotime-(Y) & $\begin{array}{c}\text { Xenotime-(Y) } \\
\text { Dy-rich }\end{array}$ & $\begin{array}{c}\text { Unnamed } \\
\text { mineral }\end{array}$ \\
\hline $\mathrm{CO}_{2}$ & - & - & $16.71 \pm 2.00$ & - & - & - & 8.98 \\
\hline $\mathrm{P}_{2} \mathrm{O}_{5}$ & 0.02 & 0.03 & $0 . \overline{05}$ & $27.71 \pm 0.41$ & $32.72 \pm 1.56$ & 30.81 & 25.43 \\
\hline $\mathrm{SiO}_{2}$ & 0.04 & 0.22 & $0.15+0.03$ & $0 . \overline{7} 0$ & $0.37 \pm 0.14$ & 0.55 & 0.30 \\
\hline $\mathrm{Al}_{2} \mathrm{O}_{3}$ & 0.01 & 0.03 & $0 . \overline{0} 1$ & d.l. & d.l. & n.d. & 0.12 \\
\hline $\mathrm{CaO}$ & $69.20 \pm 1.62$ & 0.83 & $1.43 \pm 0.22$ & 2.76 & $0.17 \pm 0.15$ & 0.31 & 5.64 \\
\hline $\mathrm{FeO}$ & $0 . \overline{0} 2$ & d.l. & d. $\bar{l}$. & 0.31 & $0 . \overline{02}$ & d.l. & 0.12 \\
\hline $\mathrm{Y}_{2} \mathrm{O}_{3}$ & $0.45 \pm 0.19$ & 1.39 & $1.22 \pm 0.54$ & 10.16 & $37.45 \pm 3.07$ & 26.36 & 5.74 \\
\hline $\mathrm{La}_{2} \mathrm{O}_{3}$ & $0 . \overline{0} 2$ & 11.19 & $10.84 \pm 1.63$ & 6.02 & 0.02 & 0.02 & 5.07 \\
\hline $\mathrm{Ce}_{2} \mathrm{O}_{3}$ & 0.02 & 34.09 & $36.96 \pm 1.83$ & 15.20 & 0.06 & 0.08 & 12.04 \\
\hline $\mathrm{Pr}_{2} \mathrm{O}_{3}$ & 0.03 & 4.17 & $4.93 \pm 0.34$ & 1.88 & 0.04 & 0.06 & 1.60 \\
\hline $\mathrm{Nd}_{2} \mathrm{O}_{3}$ & 0.03 & 12.89 & $14.74 \pm 1.57$ & 7.68 & 0.10 & 0.19 & 6.18 \\
\hline $\mathrm{Sm}_{2} \mathrm{O}_{3}$ & 0.03 & 3.86 & $3.98 \pm 1.07$ & 2.42 & $0.46 \pm 0.28$ & 0.20 & 2.04 \\
\hline $\mathrm{Eu}_{2} \mathrm{O}_{3}$ & 0.01 & n.d. & $0.10 \pm 0.02$ & n.d. & $0 . \overline{02}$ & n.d. & 0.06 \\
\hline $\mathrm{Gd}_{2} \mathrm{O}_{3}$ & 0.03 & 2.55 & $1.85 \pm 0.49$ & $2.54 \pm 0.42$ & $3.59 \pm 0.93$ & 5.29 & 1.96 \\
\hline $\mathrm{Tb}_{2} \mathrm{O}_{3}$ & 0.01 & 0.20 & $0.24 \pm 0.09$ & 0.21 & $0.64 \pm 0.15$ & 1.18 & 0.28 \\
\hline $\mathrm{Dy}_{2} \mathrm{O}_{3}$ & 0.05 & 0.51 & $0.69 \pm 0.09$ & 2.20 & $6.10 \pm 1.09$ & 11.48 & 1.50 \\
\hline $\mathrm{Ho}_{2} \mathrm{O}_{3}$ & 0.02 & 0.08 & $0 . \overline{03}$ & 0.59 & $1.40 \pm 017$ & 2.06 & 0.27 \\
\hline $\mathrm{Er}_{2} \mathrm{O}_{3}$ & 0.02 & 0.21 & 0.11 & 0.98 & $5.59 \pm 0.74$ & 7.34 & 0.55 \\
\hline $\mathrm{Yb}_{2} \mathrm{O}_{3}$ & 0.04 & 0.39 & 0.07 & 0.55 & $8.46 \pm 1.59$ & 11.13 & 0.54 \\
\hline $\mathrm{Lu}_{2} \mathrm{O}_{3}$ & 0.03 & d.l. & d.l. & 0.68 & $0.36 \pm 0.09$ & 0.44 & 0.06 \\
\hline $\mathrm{ThO}_{2}$ & 0.02 & 2.13 & $0.87 \pm 0.33$ & 6.49 & $0.47 \pm 0.18$ & 0.69 & 17.91 \\
\hline $\mathrm{UO}_{2}$ & d.l. & d.l. & d.l. & $7.94 \pm 0.86$ & $0 . \overline{13}$ & 0.08 & 2.80 \\
\hline $\mathrm{PbO}$ & 0.02 & 0.75 & $0.07+0.06$ & $0 . \overline{3} 8$ & 0.02 & 0.02 & 0.46 \\
\hline $\mathrm{F}$ & $55.47 \pm 0.87$ & 30.54 & $9.74+1.58$ & n.d. & $1.51+0.89$ & n.d. & 0.68 \\
\hline$-\mathrm{O}=\mathrm{F}_{2}$ & -23.35 & -12.86 & $-4 . \overline{10}$ & - & $-0 . \overline{6} 4$ & - & -0.29 \\
\hline Total & 102.24 & 93.17 & 100.69 & 97.40 & 99.06 & 98.29 & 100.04 \\
\hline $\mathrm{n}$ & 17 & 3 & 5 & 4 & 15 & 2 & 2 \\
\hline
\end{tabular}



Table 5 Composition of zircon crystallized from graphic granite from a miarolitic pegmatite in the Königshain granite (E-Germany); oxides in mass\%

\begin{tabular}{|c|c|c|c|c|c|c|c|}
\hline \multirow{3}{*}{$\mathrm{SiO}_{2}$} & \multirow{3}{*}{$\frac{\text { d.l. }}{0.04}$} & \multicolumn{2}{|c|}{ Th: $<0.09$} & \multicolumn{2}{|c|}{ Th $>0.09$} & \multicolumn{2}{|c|}{ Hf-rich } \\
\hline & & Mean & SD & Mean & SD & & \\
\hline & & 31.74 & 0.45 & 31.38 & 0.44 & 31.74 & 31.27 \\
\hline $\mathrm{ZrO}_{2}$ & 0.11 & 59.98 & 0.74 & 57.87 & 1.77 & 53.02 & 48.49 \\
\hline $\mathrm{HfO}_{2}$ & 0.14 & 5.39 & 1.04 & 5.23 & 1.11 & 12.87 & 18.29 \\
\hline $\mathrm{Al}_{2} \mathrm{O}_{3}$ & 0.02 & 0.04 & 0.06 & 0.04 & 0.05 & 0.02 & 0.01 \\
\hline $\mathrm{FeO}$ & 0.06 & 0.17 & 0.10 & 0.11 & 0.12 & 0.04 & 0.04 \\
\hline $\mathrm{CaO}$ & 0.03 & 0.01 & 0.01 & 0.03 & 0.04 & 0.02 & 0.21 \\
\hline $\mathrm{Sc}_{2} \mathrm{O}_{3}$ & 0.03 & 0.15 & 0.07 & 0.15 & 0.10 & 0.36 & 0.54 \\
\hline $\mathrm{Y}_{2} \mathrm{O}_{3}$ & 0.05 & 0.09 & 0.09 & 0.54 & 0.49 & 0.36 & d.l. \\
\hline $\mathrm{Ce}_{2} \mathrm{O}_{3}$ & 0.08 & 0.02 & 0.01 & 0.02 & 0.01 & d.l. & d.l. \\
\hline $\mathrm{Nd}_{2} \mathrm{O}_{3}$ & 0.10 & 0.03 & 0.02 & 0.02 & 0.01 & 0.03 & 0.01 \\
\hline $\mathrm{Sm}_{2} \mathrm{O}_{3}$ & 0.12 & 0.03 & 0.01 & 0.04 & 0.02 & d.l. & 0.01 \\
\hline $\mathrm{Gd}_{2} \mathrm{O}_{3}$ & 0.12 & 0.03 & 0.01 & 0.08 & 0.05 & 0.07 & 0.05 \\
\hline $\mathrm{Dy}_{2} \mathrm{O}_{3}$ & 0.13 & 0.02 & 0.02 & 0.05 & 0.03 & d.l. & 0.02 \\
\hline $\mathrm{Yb}_{2} \mathrm{O}_{3}$ & 0.08 & 0.65 & 0.37 & 1.02 & 0.42 & 0.66 & 0.38 \\
\hline $\mathrm{ThO}_{2}$ & 0.08 & 0.04 & 0.02 & 0.59 & 0.48 & 0.03 & 0.10 \\
\hline $\mathrm{UO}_{2}$ & 0.10 & 1.04 & 0.41 & 1.88 & 0.73 & 1.26 & 1.08 \\
\hline $\mathrm{PbO}$ & 0.06 & 0.05 & 0.02 & 0.09 & 0.04 & 0.05 & 0.08 \\
\hline $\mathrm{P}_{2} \mathrm{O}_{5}$ & 0.09 & 0.12 & 0.10 & 0.14 & 0.11 & 0.68 & 0.07 \\
\hline Total & & 99.60 & 1.00 & 99.28 & 0.93 & 101.21 & 100.63 \\
\hline $\mathrm{n}$ & & 16 & & 11 & & 1 & 1 \\
\hline$\sum \mathrm{REE}_{2} \mathrm{O}_{3}+\mathrm{Y}_{2} \mathrm{O}_{3}$ & & 0.87 & & 1.77 & & 0.76 & 0.47 \\
\hline $\mathrm{Zr} / \mathrm{Hf}$ & & 11.13 & & 11.06 & & 4.12 & 2.65 \\
\hline Age [Ma] & & 322 & 30 & 318 & 30 & 281 & n.d. \\
\hline $\begin{array}{l}\text { d.l. - detec } \\
\text { SD - stand } \\
\mathrm{n} \text { - number }\end{array}$ & $\begin{array}{l}(20) \\
\text { tion }\end{array}$ & $40 \mathrm{nA}$ & & & & & \\
\hline
\end{tabular}


Fig. 1

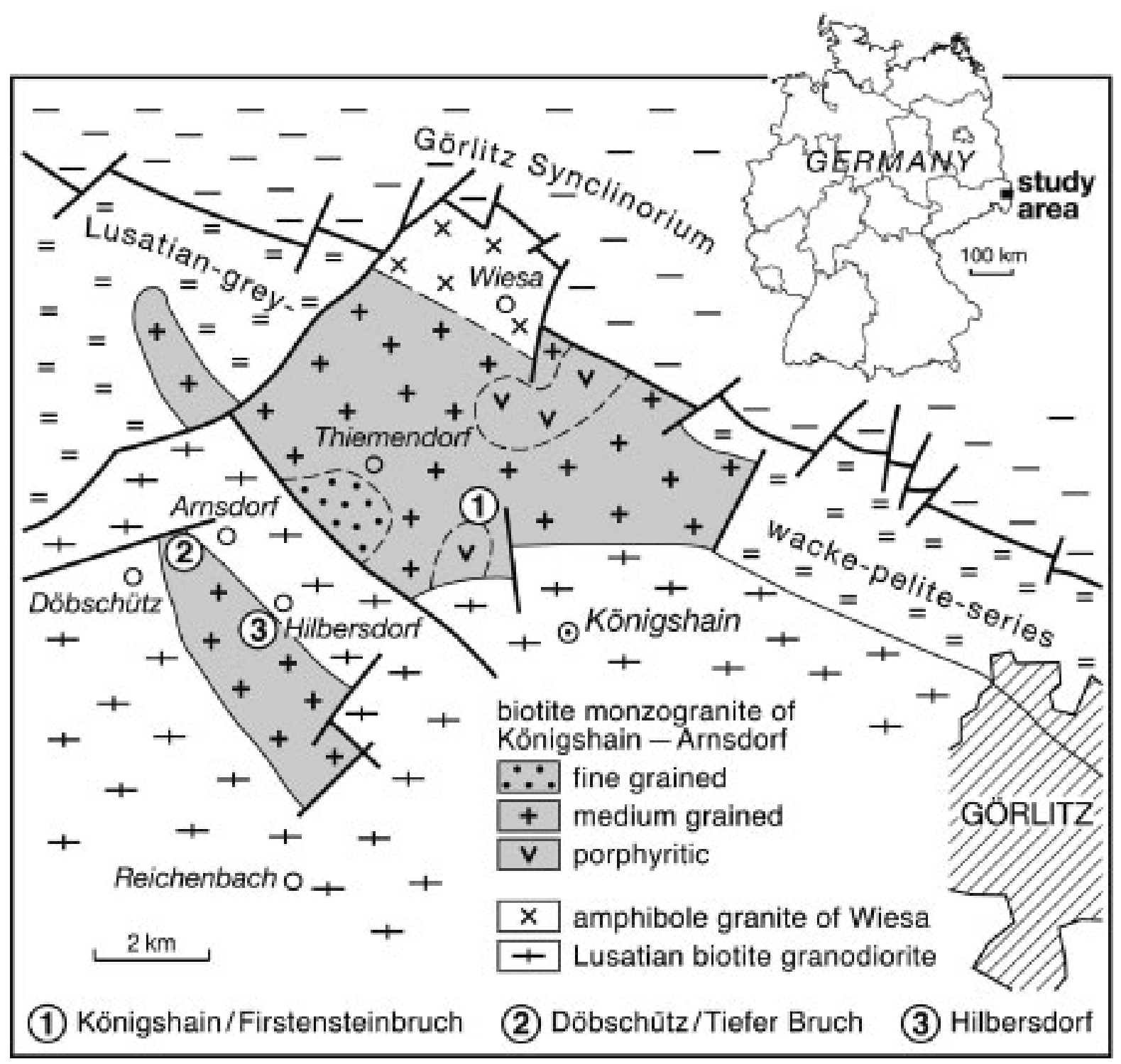


Fig. 2

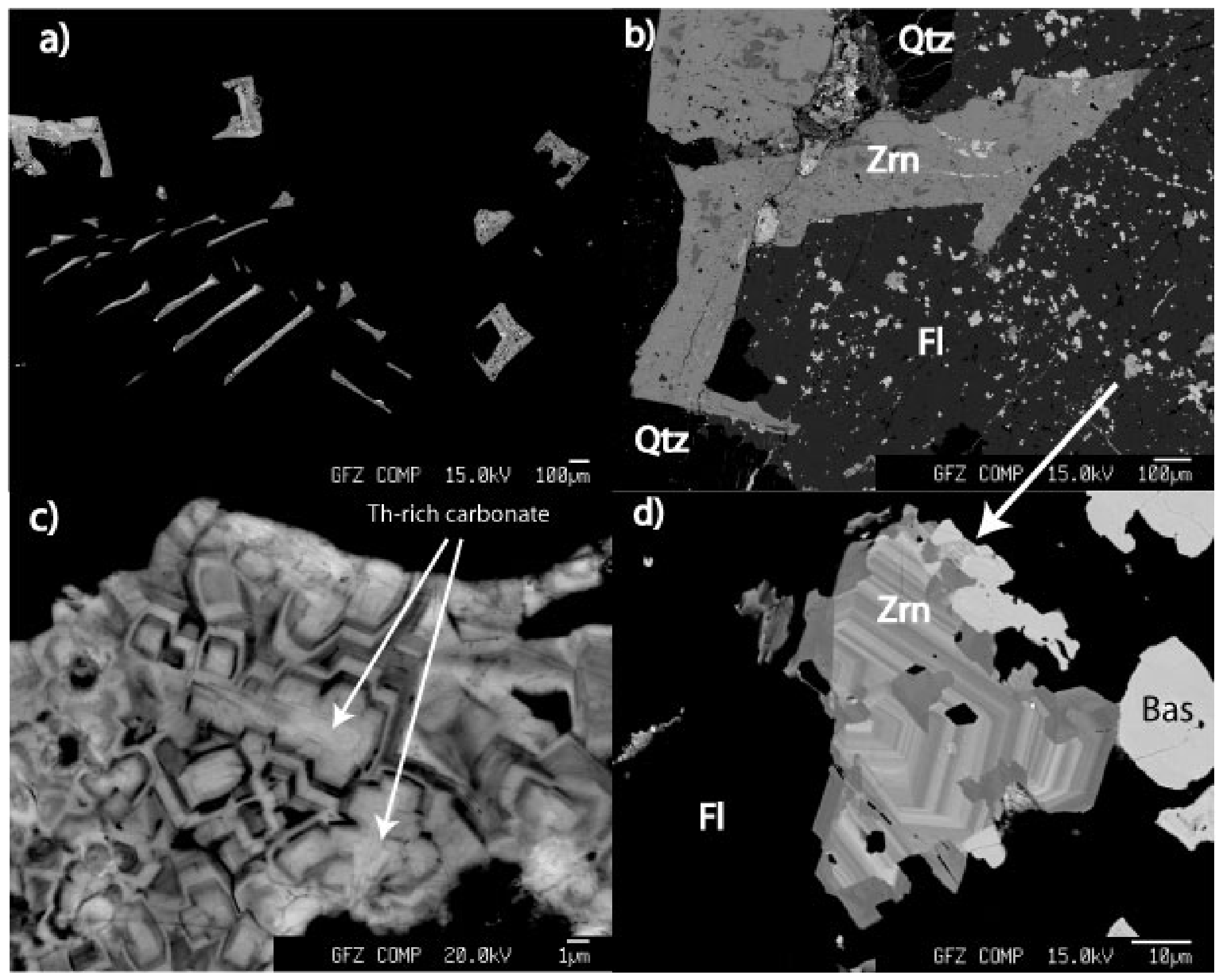


Fig. 3

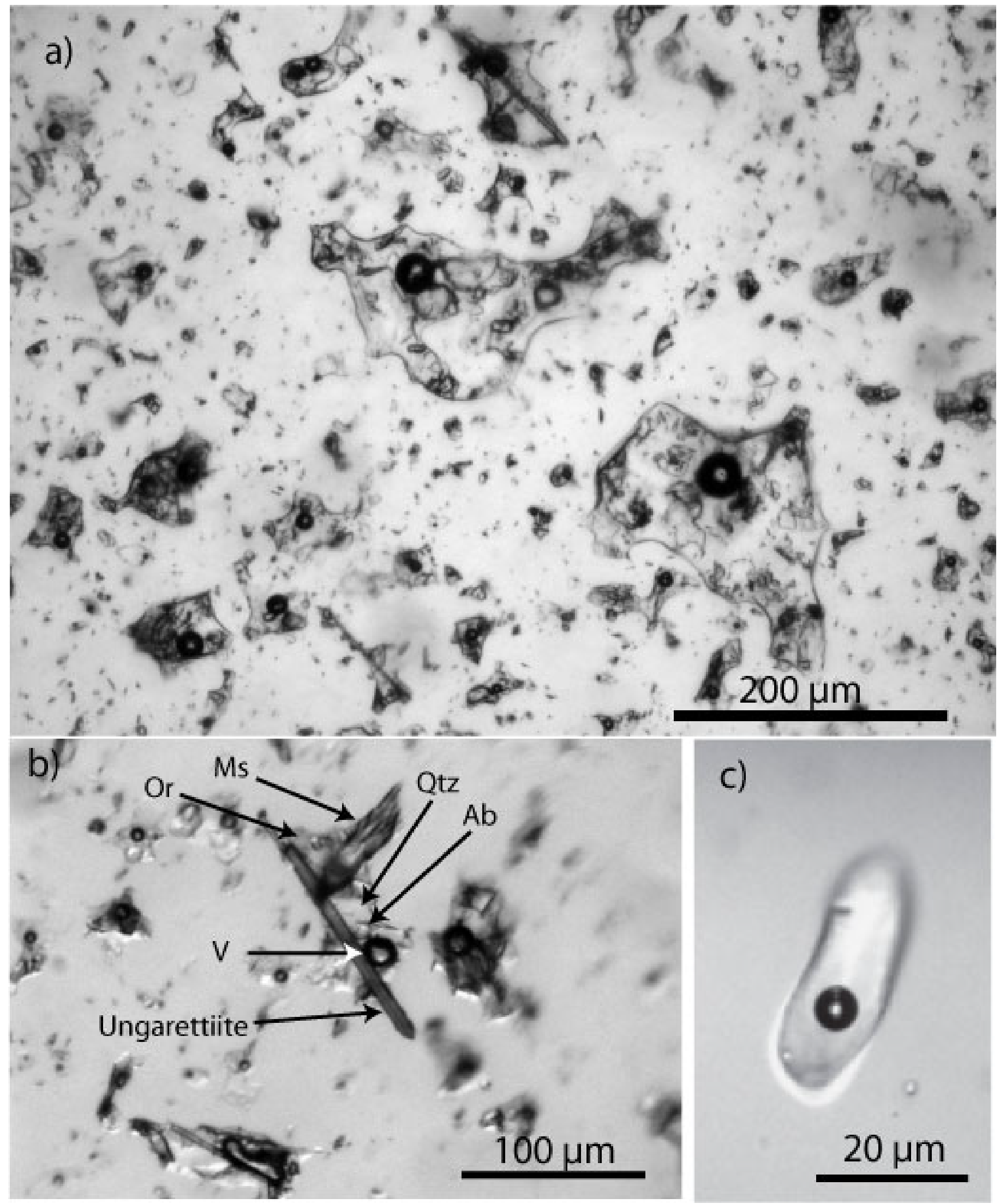


Fig. 4

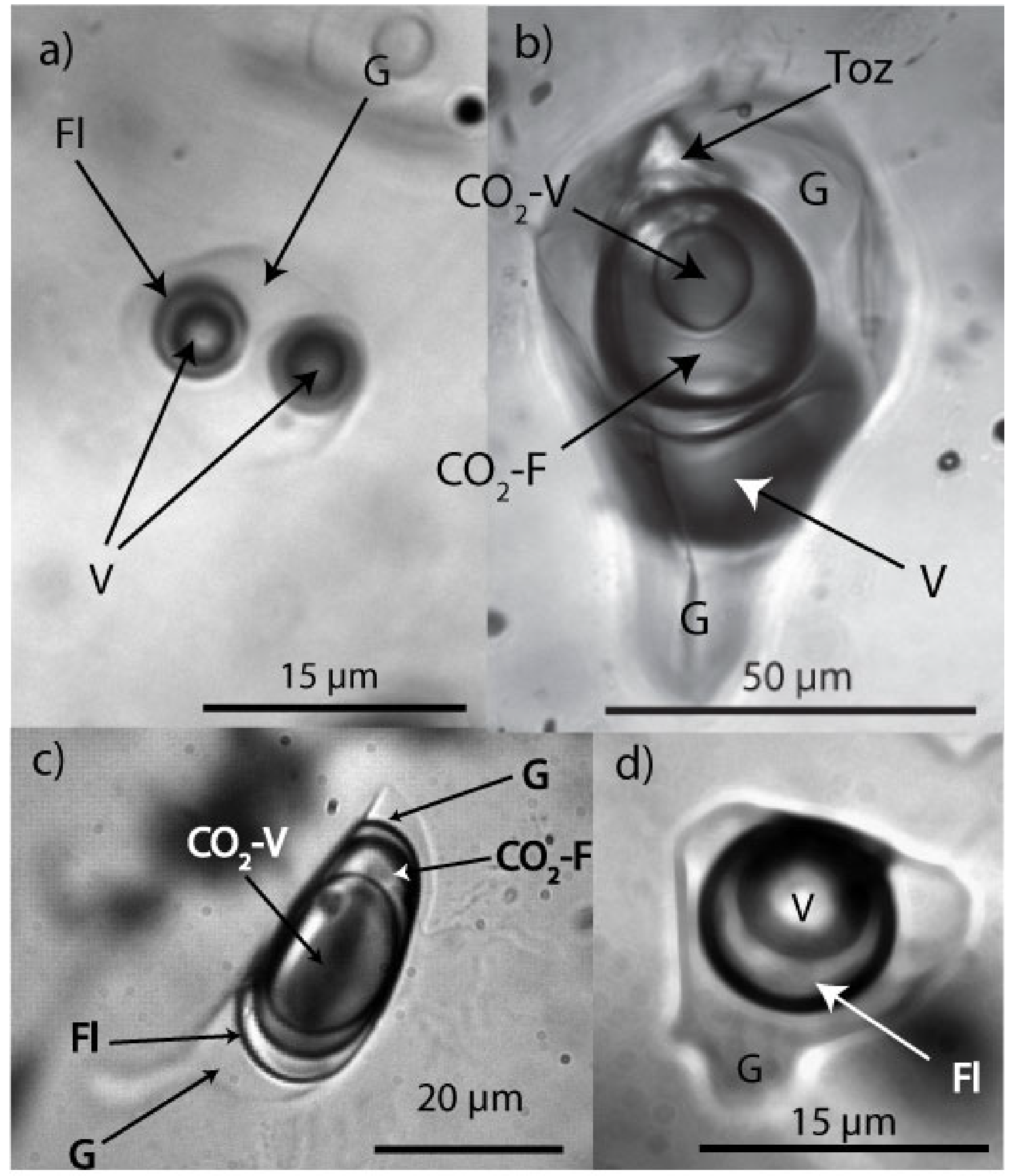


Fig. 5

a)
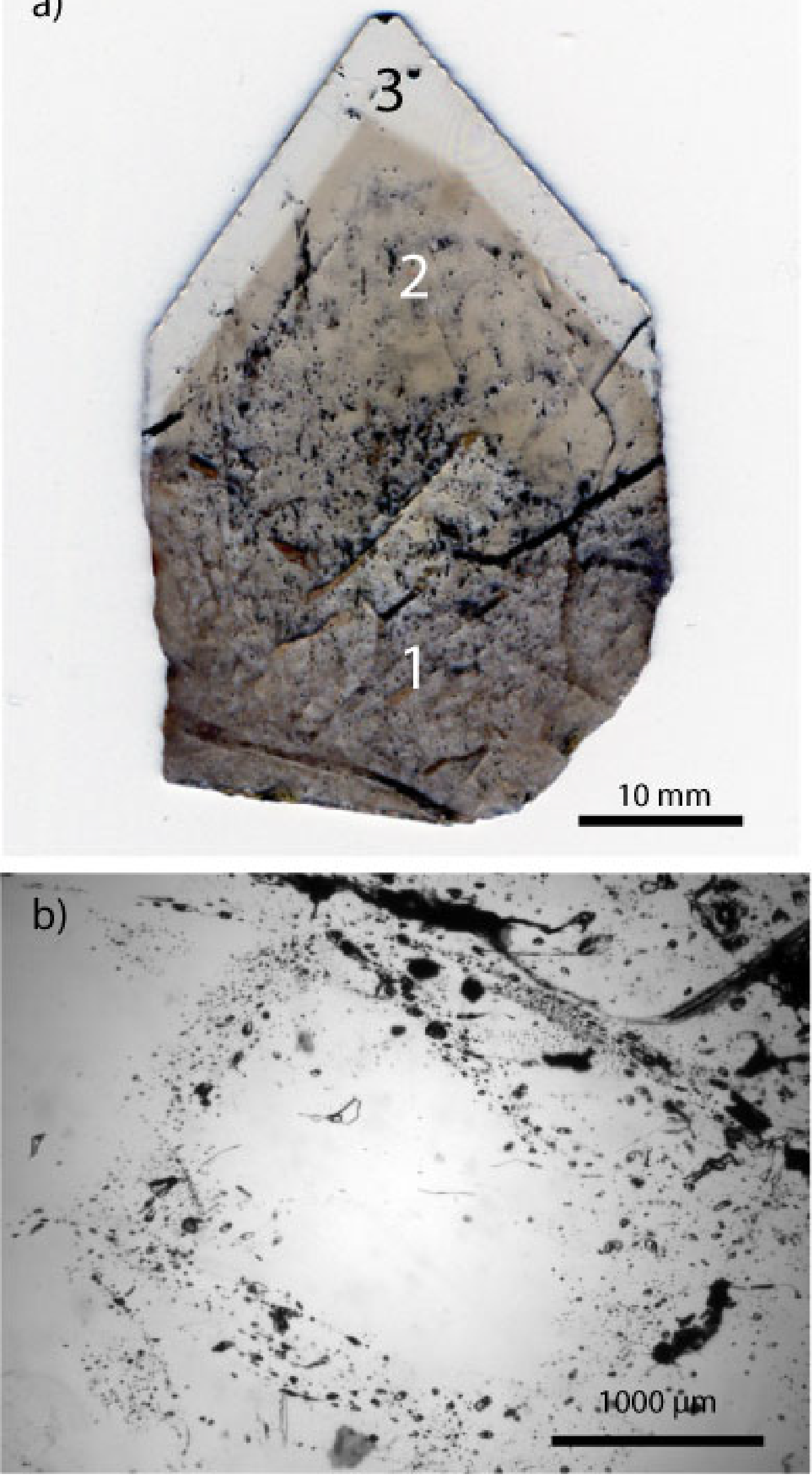
Fig. 6

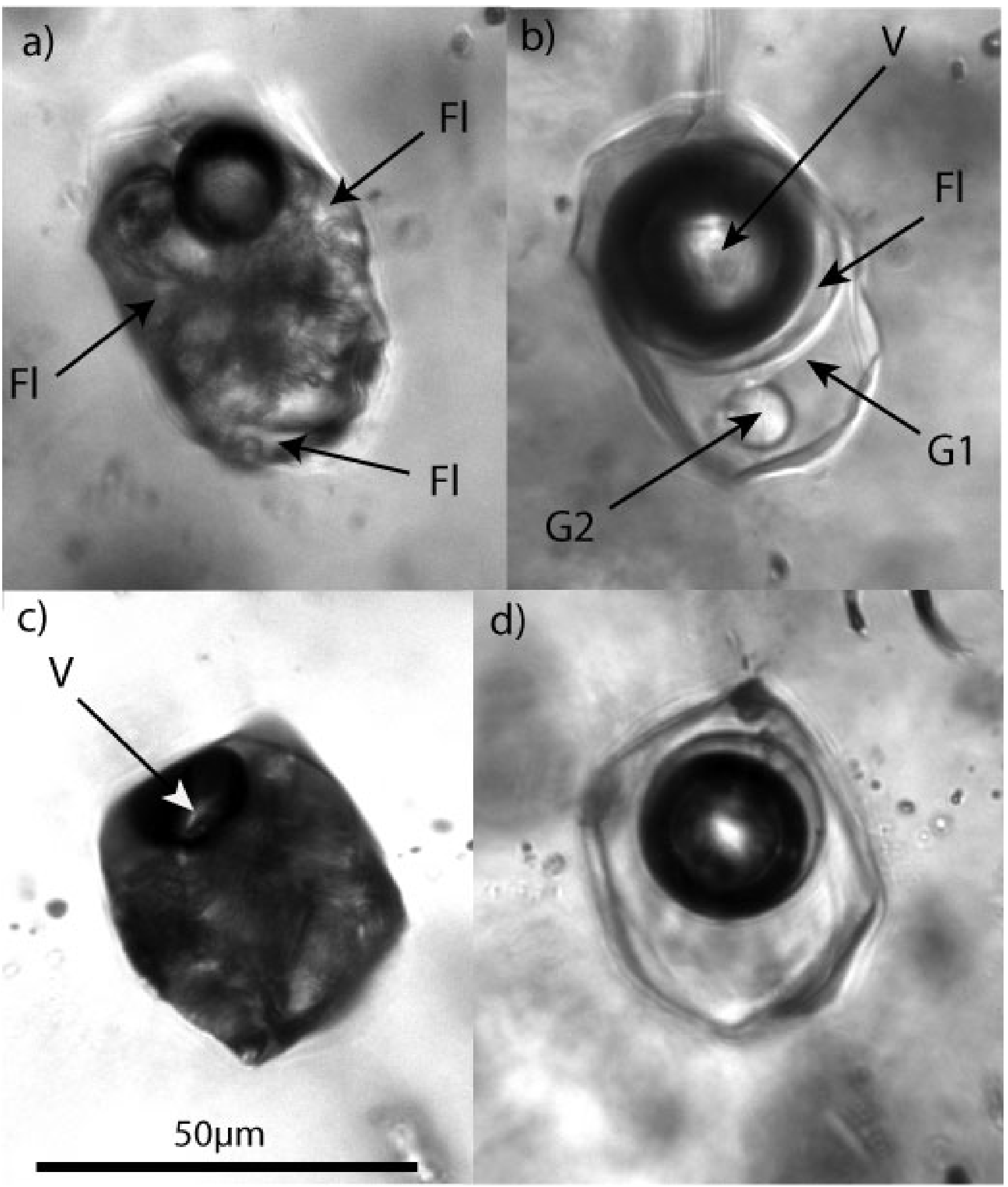


Fig. 7

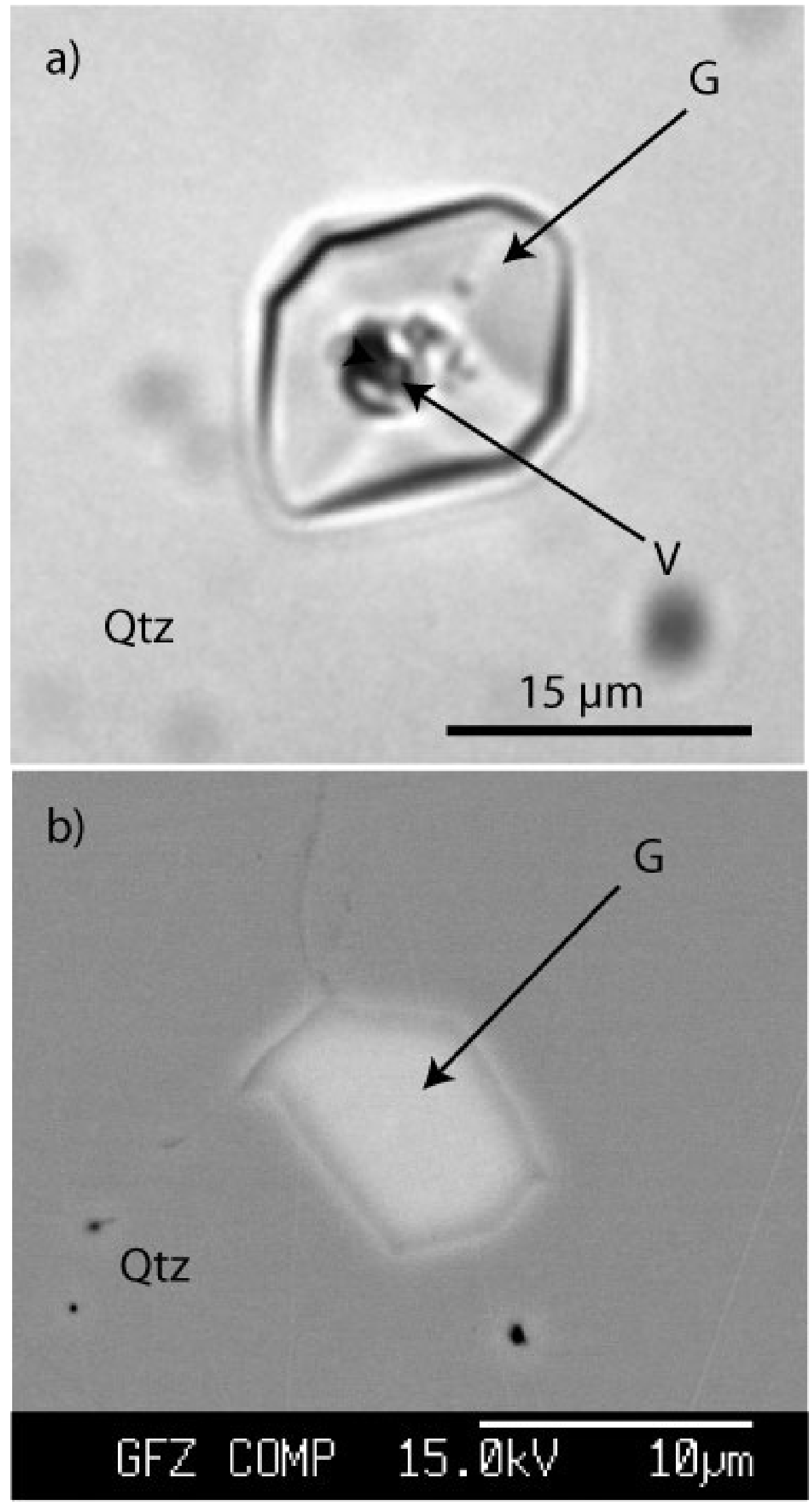


Fig. 8

a)

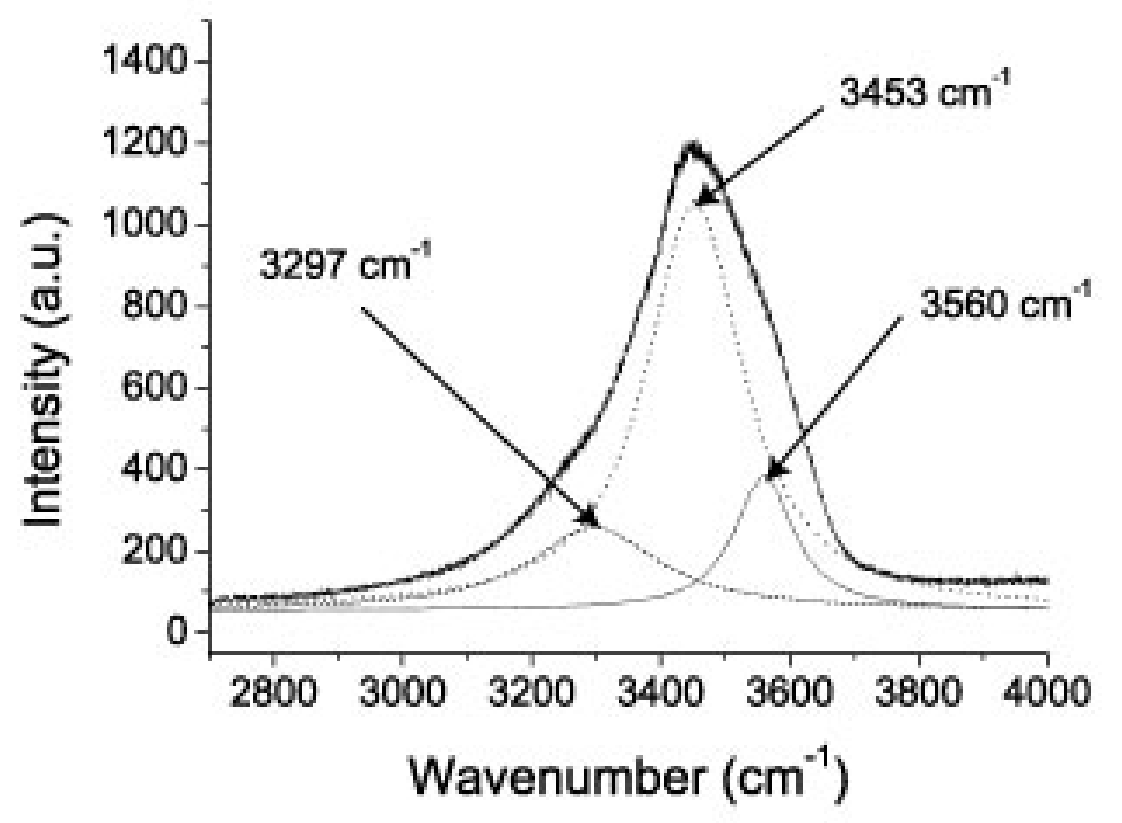

b)

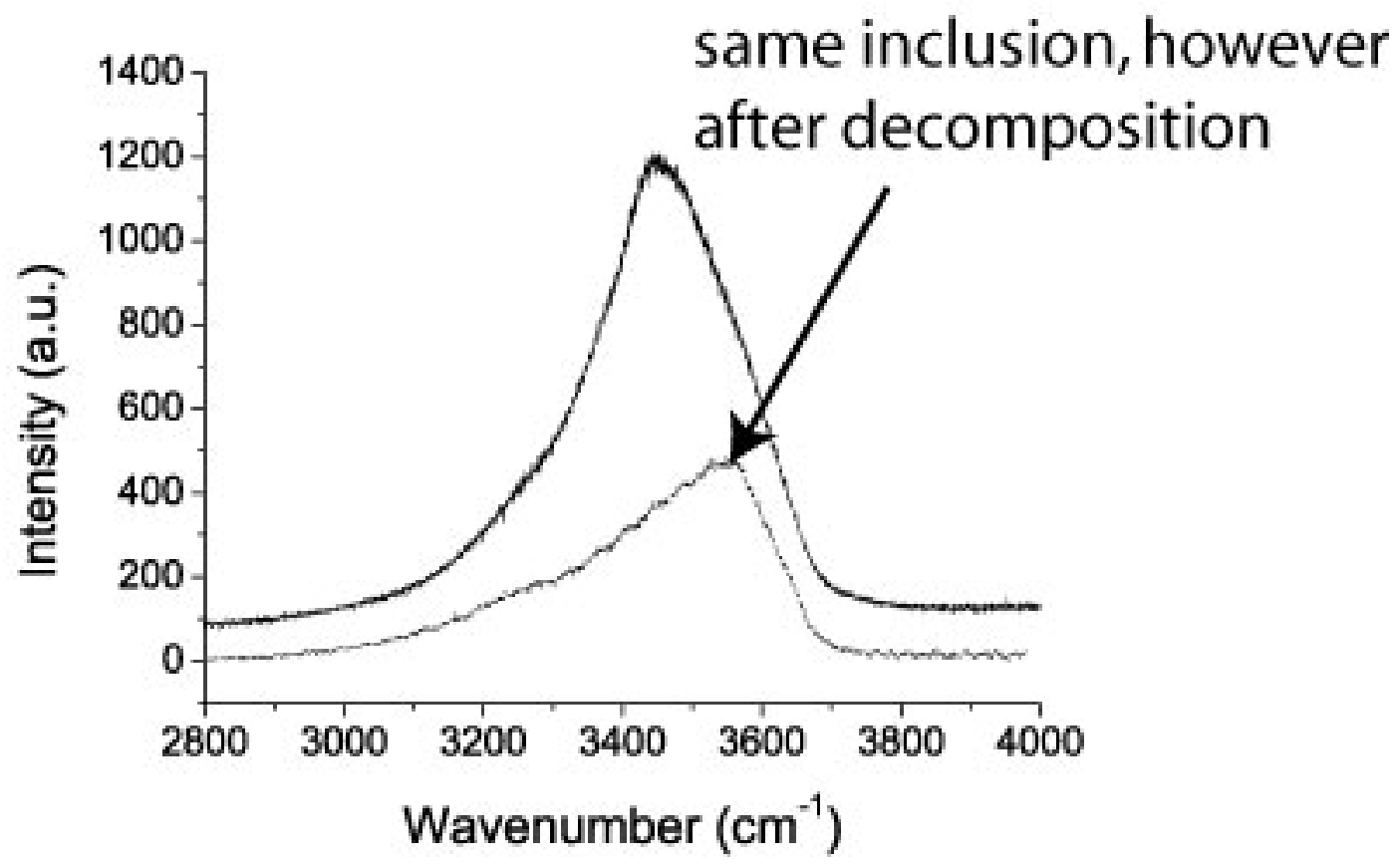




\section{Electronic supplementary material}

\section{Experimental and analytical methods}

\section{Homogenization experiments}

\section{Cold-seal pressure vessel homogenization experiments}

Because the melt inclusions in pegmatite were completely crystallised it was necessary to rehomogenize the inclusions to a homogeneous, daughter crystal-free glass for electron microprobe and Raman spectroscopic studies. Quartz grains containing melt inclusions from the graphic granite were homogenized using conventional horizontal cold-seal pressure vessel technique in GeoForschungsZentrum (GFZ) Potsdam (the procedure is described by Thomas et al. 2000). Here, doubly polished plates of graphic granite or quartz were placed into an open Au capsule (30 mm long, $5 \mathrm{~mm}$ diameter). The vessel was pressurized with $\mathrm{CO}_{2}$ to 1,2 or $3 \mathrm{kbar}$, and the sample moved into the preheated furnace $\left(600,650\right.$ and $700^{\circ} \mathrm{C}$ respectively). The run time was 20 hours. After the experiment the Au capsule was removed from the furnace and quenched isobarically with compressed air. After quenching, the samples were removed, re-polished and mounted on glass disks for the determination of the bulk composition using microprobe techniques, and of water content by confocal micro-Raman spectroscopy.

\section{Hydrothermal rapid-quench homogenization experiments}

Double-polished plates of smoky quartz (500 $\mu$ m thick) were placed into an Au-capsule (5 x 30 $\mathrm{mm}$ ) with a fixed amount of pure water. The inclusions were re-melted at $650^{\circ} \mathrm{C}$ and a pressure of 1 kbar using the conventional hydrothermal rapid quench technique. The run time of the unbuffered experiments was 20 hours. After the run, the sample was quenched isobarically.

\section{Homogenization experiments at ambient pressure}

Although not obvious visually, homogenization of melt inclusions in quartz using the LINKAM TH1500 microscope heating stage failed because of water loss by diffusion or simple leakage via micro-cracks. This is indicated by fact that the temperature data obtained were always more than $100^{\circ} \mathrm{C}$ higher than obtained by step-heating using pressurized cooled sealed vessel experiments (see Thomas, 1994) and the homogenization temperatures increase strongly with duration of heating. The inclusions would homogenize, and did give homogenization temperatures, but the resultant data 
contained significant errors $\left(>100^{\circ} \mathrm{C}\right)$. We would suggest that homogenizations at ambient pressure may be a risky technique in pegmatite studies, without some form of confirmation.

\section{Microthermometry of aqueous fluid inclusions}

Microthermometric measurements were performed using a calibrated LINKAM THMS 600 heating and freezing stage, together with a TMS92 temperature programmer and a LNP2 cooling system mounted on an Olympus microscope. The stage was calibrated with synthetic fluid inclusions (SYNFLINC) and melting points of different standards. All measurements were performed under argon. The standard deviation depends on absolute temperature and is always less than $\pm 2.5^{\circ} \mathrm{C}$ for temperatures greater $100^{\circ} \mathrm{C}$, and is $\leq 0.2^{\circ} \mathrm{C}$ for cryometric measurements lower than $20^{\circ} \mathrm{C}$. Samples were 300- $\mu$ m-thick, doubly polished graphic granite, smoky quartz, albite, schorl and fluorite chips.

The salinity of the inclusions was estimated using the empirical equations (Bakker, 2003; program AqSo2e, version 03/02) for freezing-point-depression of aqueous solutions corresponding to the $\mathrm{CaCl}_{2}-\mathrm{NaCl}-\mathrm{H}_{2} \mathrm{O}$ system with one or two dissolved salts.

For solutions with significant amounts of carbonates we used the system $\mathrm{Na}_{2} \mathrm{CO}_{3}-\mathrm{NaCl}-\mathrm{H}_{2} \mathrm{O}$ (Makarov, 1933) for the cryometric measurements, and the cryometric criteria demonstrated by Borisenko (1977). Therefore the determined carbonate concentrations are $\mathrm{Na}_{2} \mathrm{CO}_{3}$ equivalent concentrations. According to Nývlt (1977) the solubility of the main alkali carbonates (Li, Na, K) at $20^{\circ} \mathrm{C}$ are $1.31,18.1,52.5$ mass $\%$, respectively.

\section{Micro-Raman spectroscopy and water determination in the inclusion glass}

Raman spectroscopy is a very sensitive technique which requires minimal sample volume and preparation. In addition, Raman spectroscopy is generally non-destructive, and can be used to identify a wide range of minerals (see Downs, 2006). Because water is a weak scatterer of Raman radiation, Raman spectra can be obtained from daughter minerals immersed in water (i.e., in aqueous fluid inclusions). Modern confocal Raman microprobes have a lateral resolution of $\sim 1 \mu \mathrm{m}$ and a depth resolution of $\sim 2 \mu \mathrm{m}$ which allow confocal spectral measurements from selected regions inside mineral samples and this enables the characterization of daughter minerals in inclusions.

Raman spectra were recorded with a Jobin-Yvon LabRam HR800 spectrometer (grating: 2400 $\mathrm{gr} / \mathrm{mm}$ ), equipped with an Olympus optical microscope and a long-working-distance LMPlanFI 100x/0.80 objective. We used a $488 \mathrm{~nm}$ excitation of a Coherent $\mathrm{Ar}^{+}$laser Model Innova 70C, a power of $300 \mathrm{~mW}$ (about $45 \mathrm{~mW}$ on sample), at a resolution $\leq 0.6 \mathrm{~cm}^{-1}$. Each unpolarized spectrum represents the accumulation of six acquisitions of 20 seconds each. The spectra were collected at a constant laboratory temperature $\left(20^{\circ} \mathrm{C}\right)$ with a Peltier-cooled CCD detector and the positions of the Raman bands were controlled and eventually corrected using the principal plasma lines in the Argon 
laser. The recommended and measured positions of the plasma lines in the fingerprint spectral region are not larger than $0.6 \mathrm{~cm}^{-1}$.

Water concentrations of some of the volatile-rich, type-A and type-B melt inclusions from the graphic granite and smoky quartz from the miarolitic cavities were determined by confocal Raman spectroscopy following the method by Thomas (2000) and Thomas et al. (2006). Each unpolarized spectrum was collected 11 times, with a counting time of $50 \mathrm{~s}$ for each accumulation. A synthetic glass with a total of $6.53 \mathrm{wt} \% \mathrm{H}_{2} \mathrm{O}_{\mathrm{T}}$, determined by Karl Fischer titration, was used as a reference standard.

Carbonates in the fluid phases (type-B melt inclusions and fluid inclusions) were determined with Raman spectroscopy according to Oliver and Davis (1973) using the relationship of the concentration and the band position between $1376 \mathrm{~cm}^{-1}(8.0 \mathrm{~mol} / \mathrm{l})$ and $1382 \mathrm{~cm}^{-1}(0.01 \mathrm{~mol} / \mathrm{l})$. Note that the carbonate frequencies are virtually independent of alkali metal cations ( $\mathrm{Li}, \mathrm{Na}, \mathrm{K}, \mathrm{Rb}, \mathrm{Cs})$.

\section{Microprobe techniques}

After quenching, the quartz grains were polished down until the homogenized glass inclusions were exposed. They were analyzed with a Cameca SX50 and a SX100 electron microprobe at GFZ, Potsdam using following analytical conditions: accelerating voltage of $15 \mathrm{kV}$, beam current of $10 \mathrm{nA}$, beam size of 2-40 $\mu \mathrm{m}$, counting time $20 \mathrm{~s}$ on peak for $\mathrm{Si}, \mathrm{Al}, \mathrm{Na}, \mathrm{K}, \mathrm{Ca}, \mathrm{Fe}, \mathrm{Mg}, \mathrm{Mn}$, and Ti, $40 \mathrm{~s}$ for F, P, $\mathrm{Cl}$ and $\mathrm{Rb}$, and $120 \mathrm{~s}$ for Sn. Synthetic oxides and minerals were used as standards.

Zircon, monazite and xenotime crystals were analysed using the CAMECA SX-50 electron microprobe operated at $20 \mathrm{kV}$ accelerating potential, $40 \mathrm{nA}$ current, and $2 \mu \mathrm{m}$ beam diameter (for details see Rhede et al. 1996). Standards were well-characterized natural and synthetic materials (e.g. zircon, oxides, REE-phosphates).

Additional measurements of REE-minerals were carried out with a JEOL thermal field emission electron-probe JXA-8500 F (HYPERPROBE) at GFZ. Beam conditions were an accelerating voltage of $20 \mathrm{kV}$, a beam current of $10 \mathrm{nA}$, and different beam diameters depending on the size of the grains (focussed beam or 1-2 $\mu \mathrm{m}$ beam diameter). The counting times on the peak are $20 \mathrm{~s}$ for Fe and Zr, $30 \mathrm{~s}$ for F, Al, Si, P and Ca and 50 s for Y, REEs, Hf, Pb, Th and U. The matrix corrections were performed following the Armstrong-CITZAF method (Armstrong 1991). X-ray lines and background offsets were selected to minimize interferences or were empirically corrected (e.g. Åmli and Griffin 1975; Roeder 1985).

Thomas R (1994) Fluid evolution in relation to the emplacement of the Variscan granites in the Erzgebirge region: A review of the melt and fluid inclusion evidence. In: Seltmann, Kämpf \& Möller (eds.) Metallogeny of Collisional Orogens. Czech Geological Survey, Prague, pp $70-81$ 